\title{
Frequency-Dependent, Cell Type-Divergent Signaling in the Hippocamposeptal Projection
}

\author{
Joanna Mattis, ${ }^{1,2 *}$ Julia Brill, ${ }^{3 \star}$ Suzanne Evans, ${ }^{7}$ Talia N. Lerner, ${ }^{2}$ (1) Thomas J. Davidson, ${ }^{2}$ Minsuk Hyun, ${ }^{2}$ \\ (1) Charu Ramakrishnan, ${ }^{2}$ Karl Deisseroth, ${ }^{2,4,5,6}$ and John R. Huguenard ${ }^{3}$ \\ ${ }^{1}$ Neuroscience Program, ${ }^{2}$ Department of Bioengineering, ${ }^{3}$ Department of Neurology and Neurological Science, ${ }^{4}$ Howard Hughes Medical Institute, \\ ${ }^{5}$ Department of Psychiatry and Behavioral Sciences, ${ }^{6}$ Cracking the Neural Code Program, Stanford University, Stanford, California 94305, and 7 Department \\ of Economics, Mathematics and Statistics, Birkbeck, University of London, Bloomsbury, London WC1E 7HX
}

\begin{abstract}
Hippocampal oscillations are critical for information processing, and are strongly influenced by inputs from the medial septum. Hippocamposeptal neurons provide direct inhibitory feedback from the hippocampus onto septal cells, and are therefore likely to also play an important role in the circuit; these neurons fire at either low or high frequency, reflecting hippocampal network activity during theta oscillations or ripple events, respectively. Here, we optogenetically target the long-range GABAergic projection from the hippocampus to the medial septum in rats, and thereby simulate hippocampal input onto downstream septal cells in an acute slice preparation. In response to optogenetic activation of hippocamposeptal fibers at theta and ripple frequencies, we elicit postsynaptic GABAergic responses in a subset (24\%) of septal cells, most predominantly in fast-spiking cells. In addition, in another subset of septal cells (19\%) corresponding primarily to cholinergic cells, we observe a slow hyperpolarization of the resting membrane potential and a decrease in input resistance, particularly in response to prolonged high-frequency (ripple range) stimulation. This slow response is partially sensitive to GIRK channel and D2 dopamine receptor block. Our results suggest that two independent populations of septal cells distinctly encode hippocampal feedback, enabling the septum to monitor ongoing patterns of activity in the hippocampus.
\end{abstract}

Key words: hippocamposeptal; medial septum; optogenetics

\section{Introduction}

The hippocampus exhibits distinct oscillatory patterns, including theta $(4-12 \mathrm{~Hz})$ and ripples $(150-200 \mathrm{~Hz})$, which are thought to be critical to information processing. Theta is believed to represent the "online" state of the hippocampus, facilitating information processing by providing temporal organization of active neuronal assemblies and modifying synaptic weights both within the hippocampus and between the hippocampus and other brain regions. Ripples, in contrast, occur when the hippocampus is working "offline": they coincide with increased hippocampalcortical communication and have demonstrated importance in memory consolidation (Girardeau et al., 2009).

Received Dec. 8, 2013; revised June 25, 2014; accepted July 21, 2014.

Author contributions: J.M., J.B., K.D., and J.R.H. designed research; J.M., J.B., T.N.L., T.J.D., M.H., and C.R. performed research; J.M., J.B., K.D., and J.R.H. contributed unpublished reagents/analytic tools; J.M., J.B., S.E., and M.H. analyzed data; J.M., J.B., and J.R.H. wrote the paper.

This work was supported by Stanford Bio-X (M.H. and J.M.); the Stanford Medical Scientist Training Program (J.M.); National Institute of Neurological Disorders and Stroke Grants ns034774 (J.B.), ns06477 (J.R.H.), ns34774 (J.R.H.), and n39579 (J.R.H.); the Stanford Department of Bioengineering (C.R.); a Stanford Dean's Postdoctoral Fellowship (T.N.L.); a Berry Postdoctoral Fellowship (T.J.D.); the National Institute of Mental Health (K.D.); the National Institute on Drug Abuse (K.D.); the Defense Advanced Research Projects Agency (K.D.); and the Gatsby Foundation (K.D.). We thank M. Warden, C. Christian, I. Parada, S. Lee, F. Zhang, I. Witten, and K. Tye for helpful discussions, and all members of the Huguenard and Deisseroth laboratories for their support.

*J.M. and J.B. contributed equally to this work.

The authors declare no competing financial interests.

Correspondence should be addressed to either of the following: John R. Huguenard at the above address, E-mail: john.huguenard@stanford.edu; or Karl Deisseroth at the above address, E-mail: deissero@stanford.edu.

DOI:10.1523/JNEUROSCI.5188-13.2014

Copyright $\odot 2014$ the authors $\quad 0270-6474 / 14 / 3311769-12 \$ 15.00 / 0$
Given the prominence of hippocampal oscillations, much effort has been devoted to determining the underlying circuitry. Although the hippocampus can in some situations intrinsically generate theta oscillations (Goutagny et al., 2009), the heavy cholinergic and GABAergic inputs from medial septum play a critical role in maintaining and pacing theta. Septal cholinergic (ChAT) cells are thought to determine the tone (amplitude) of theta (Lee et al., 1994) by tonically depolarizing pyramidal cells and basket interneurons (Chapman and Lacaille, 1999), whereas septal GABAergic cells rhythmically hyperpolarize basket cells, leading to a rhythmic disinhibition of pyramidal cells (Tóth et al., 1997) that is thought to set the pace of the theta rhythm (Gerashchenko et al., 2001). More recently, a glutamatergic cell population has also been described in septum: these cells project to hippocampus (Huh et al., 2010) and synapse locally onto inhibitory cells (Manseau et al., 2005), but their role in regulating oscillations is not yet clear.

The discovery that the hippocampus projects back to the medial septum (Freund and Antal, 1988; Tóth et al., 1993), and that these hippocamposeptal (HS) projection neurons are themselves a direct target of septal innervations (Takács et al., 2008), suggests that hippocampal network activity may result instead from more complex interactions between the two regions. HS cells are inhibitory (GABAergic) neurons located in all hippocampal subfields throughout dorsal and ventral hippocampus (Freund and Antal, 1988; Tóth et al., 1993). In addition to their long-range septal projections, HS cells send collateral projections extensively 
within the hippocampus (Gulyás et al., 2003; Jinno et al., 2007; Takács et al., 2008) and are therefore well situated to coordinate synchronous neuronal activity.

HS cells are densely innervated by local pyramidal or granule cells (Gulyás et al., 2003; Takács et al., 2008). Consequentially, their firing mirrors that of the principal hippocampal cells: during theta oscillations they fire at low frequency, phase-locked to theta, while during ripples they burst at high frequency (Jinno et al., 2007). Here, we investigated the response of cells in the medial septum to hippocampal inputs of high and low frequency, using an optogenetic approach to control the sparse, long-range HS projection with high temporal precision within an acute slice preparation. In particular, we sought to test the hypothesis that stimulation of HS afferents at different frequencies, specifically at $8 \mathrm{~Hz}$ (theta) and $50 \mathrm{~Hz}$ (ripples), elicits different postsynaptic responses in subsets of septal cells.

\section{Materials and Methods}

All experiments were performed according to protocols approved by the Stanford Institutional Animal Care and Use Committee.

Viral production and stereotactic injections. The $2 \mathrm{~kb}$ mouse somatostatin (SST) promoter was amplified from mouse (C57BL/6) genomic DNA and cloned into an adeno-associated virus (AAV) vector using Mlu1 and BspE1 restriction sites. The promoter was placed directly upstream of mammalian codon-optimized ChR2(H134R) fused in-frame with enhanced yellow fluorescent protein (eYFP), followed by the expressionenhancing woodchuck hepatitis virus post-transcriptional regulatory element. The construct was fully sequenced to check for accuracy of the cloning procedure. AAV serotype 2 was produced by the University of Carolina (UNC) Chapel Hill Vector Core. Viral titers were $2-3 \times 10^{12}$ colony forming units (cfu) per ml. Wild-type 3-4-week-old male LongEvans rats were injected bilaterally in dentate gyrus and CA1, with the following coordinates ( $\mathrm{mm}$ from bregma): -3.8 anteroposterior, 2.0 mediolateral, 2.5 and 3.5 dorsoventral; -4.6 anteroposterior, 2.5 mediolateral, 2.4 and 3.6 dorsoventral.

To identify cholinergic cells in ChAT::Cre transgenic rats, a Credependent, eYFP-expressing virus of AAV serotype 5 was produced by the UNC Chapel Hill Vector Core at a genomic titer of $1 \times 10^{12} \mathrm{cfu}$ per ml. Male ChAT::Cre transgenic Long-Evans rats 3.5-4.5 months old were injected in the medial septum, using a $10^{\circ}$-angle approach to reach the following coordinates ( $\mathrm{mm}$ from bregma): +1.0 anteroposterior, 0.0 mediolateral, 7.3 dorsoventral; +0.7 anteroposterior, 0.0 mediolateral, 6.6 dorsoventral.

Slice/tissue preparation. Long-Evans rats 3-8 months old were deeply anesthetized using $50 \mathrm{mg} / \mathrm{kg}$ sodium pentobarbital and perfused transcardially with $40 \mathrm{ml}$ ice-cold sucrose solution. Brains were removed and immediately transferred to ice-cold sucrose solution, which contained the following (in mM): 234 sucrose, 11 glucose, $26 \mathrm{NaHCO}_{3}, 2.5 \mathrm{KCl}, 1.25$ $\mathrm{NaH}_{2} \mathrm{PO}_{4}, 10 \mathrm{MgSO}_{4}$, and $0.5 \mathrm{CaCl}_{2}$, equilibrated with $95 \% \mathrm{O}_{2} / 5 \% \mathrm{CO}_{2}$. Coronal slices measuring $300 \mu \mathrm{m}$ each were sectioned on a VT $1000 \mathrm{~S}$ (wild-type rats) or $1200 \mathrm{~S}$ (ChAT::Cre rats) vibratome (Leica) at $4^{\circ} \mathrm{C}$ in sucrose solution and transferred into a holding chamber filled with artificial CSF (ACSF; in mM: $126 \mathrm{NaCl}, 26 \mathrm{NaHCO}_{3}, 2.5 \mathrm{KCl}, 1.25 \mathrm{NaH}_{3} \mathrm{PO}_{4}$, $2 \mathrm{CaCl}_{2}, 2 \mathrm{MgCl}_{2}, 10$ glucose, equilibrated with $95 \% \mathrm{O}_{2} / 5 \% \mathrm{CO}_{2}, \mathrm{pH}$ 7.4). After a recovery period of $1 \mathrm{~h}$ at $32^{\circ} \mathrm{C}$, the holding chamber containing the slices was removed from the water bath and allowed to cool to room temperature.

Electrophysiology and optogenetic activation. Slices were transferred to a recording chamber and constantly superfused with oxygenated ACSF at a rate of $\sim 2 \mathrm{ml} / \mathrm{min}$. All experiments were conducted at $30-32^{\circ} \mathrm{C}$; all cells recorded were located in the medial septum/diagonal band of Broca (MSDB) or hippocampus. Presence of eYFP-expressing fibers in the MSDB was verified after conclusion of electrophysiological recordings. Whole-cell voltage-clamp and current-clamp recordings were obtained using borosilicate glass electrodes with a tip resistance of 2-4 M $\Omega$. The pipette solution contained (in $\mathrm{mm}$ ) the following: $120 \mathrm{~K}$-gluconate, 11 $\mathrm{KCl}, 1 \mathrm{MgCl}_{2}, 1 \mathrm{CaCl}_{2}, 10$ HEPES, 10 EGTA, pH 7.3, adjusted with KOH.
For patching in ChAT::Cre rats, the pipette solution additionally contained Na-GTP (0.3 mm; Sigma-Aldrich). For patching in wild-type rats, signals were amplified with a Multiclamp 700A amplifier, acquired using a Digidata 1320A digitizer, sampled at $10 \mathrm{kHz}$, and filtered at $3 \mathrm{kHz}$. For patching in ChAT::Cre rats, signals were amplified with a Multiclamp 700B amplifier, acquired using a Digidata 1440A digitizer, sampled at 10 $\mathrm{kHz}$, and filtered at $2 \mathrm{kHz}$. ChR2-expressing fibers were optically activated using a blue laser ( $473 \mathrm{~nm}$ wavelength; OEM Laser Systems) delivered through an optic fiber ( $300 \mu \mathrm{m}$ diameter; Thorlabs). Light intensity ranged from 15 to $20 \mathrm{~mW}$ and stimulation duration was $5 \mathrm{~ms}$. The optic fiber was directed to obtain illumination of the region surrounding the recorded cell's soma. Optogenetically evoked IPSCs recorded in voltageclamp mode at a holding potential of $-40 \mathrm{mV}, 5-12$ traces were averaged, and synaptic failures were included in the analysis. Neuronal firing patterns were assessed in current-clamp mode by giving a series of hyperpolarizing and depolarizing current injections ( $0.5 \mathrm{~s}$ each), typically -100 to $+200 \mathrm{pA}$ in $25 \mathrm{pA}$ increments. To record action potential waveforms, single spikes were evoked by giving one brief, high-amplitude depolarizing current injection (typically +200 to $+400 \mathrm{pA}$ for $1 \mathrm{~ms}$ ). Changes in input resistance were monitored during current-clamp recordings by giving $150 \mathrm{~ms}$ hyperpolarizing current injections (5-25 pA, depending on the cell's initial input resistance) at a frequency of $1 \mathrm{~Hz}$. Pharmacological reagents were applied via the bath solution, including the following: $\mathrm{GABA}(\mathrm{A})$ receptor antagonist picrotoxin $(50 \mu \mathrm{M}$; Tocris Bioscience), GIRK-channel antagonist barium (100 $\mu \mathrm{M}$; Sigma-Aldrich), GABA(B) receptor antagonist CGP 55845 hydrochloride (100 nM; Tocris Bioscience), nonselective SST receptor (SSTR) antagonist cyclosomatostatin ( $5 \mu \mathrm{M}$; Tocris Bioscience), SST2AR antagonist cyanamid (1 $\mu \mathrm{M}$; SigmaAldrich), SST2AR agonist octreotide ( $1 \mu \mathrm{M}$; Tocris Bioscience), muscarinic acetylcholine receptor antagonist ipratropium bromide (10 $\mu \mathrm{M}$; Tocris Bioscience), Al adenosine receptor antagonist 1,3-dipropyl-8-phenylxanthine ( $1 \mu \mathrm{M}$; Tocris Bioscience), D2 dopamine receptor antagonist prochlorperazine dimaleate (10 $\mu$; Tocris Bioscience), neuropeptide Y Y1 receptor antagonist BIBP 3226 ( $1 \mu \mathrm{M}$; Tocris Bioscience), $\mu$-opioid receptor antagonist cyprodime $\mathrm{HCl}$ ( $5 \mu \mathrm{m}$; Tocris Bioscience), D2 dopamine receptor agonist quinpirole (10 $\mu \mathrm{M}$; Tocris Bioscience). All reagents were dissolved according to the manufacturer's recommendations and then added to $50 \mathrm{ml}$ of ACSF to obtain the final working concentration.

Data analysis. Access resistance $\left(R_{\mathrm{a}}\right)$ and input resistance $\left(R_{\text {in }}\right)$ were monitored continually to ensure stability of the recording and data were only included when $R_{\mathrm{a}}$ was $<25 \mathrm{M} \Omega$ and $R_{\text {in }}$ was $>90 \mathrm{M} \Omega$. Analysis of action potential success rate (Fig. 1), septal cell characteristics (Fig. 2), and IPSC properties (Fig. 3) was performed using pClamp10 (Molecular Devices), followed by statistical analysis using Graphpad Prism version 5.04 for Windows (GraphPad Software; www.graphpad.com). GraphPad was also used to analyze the distribution of responses by cell type (see Fig. 7).

To analyze the slow changes in response to prolonged stimulation (Figs. 4-6), custom software written in Matlab (Mathworks) was used to extract input resistance and membrane potential at the time of each current pulse. Spurious values (for example if the measurement coincided with an action potential or some other instability in the recording) were removed manually. The statistical analysis was then performed using the $\mathrm{S}$ programming language as implemented within the S-PLUS system distributed by TIBCO Software (TIBCO Spotfire S+ Version $8.1 .1,2008)$. The $S+$ script files developed for the analysis made extensive use of the built-in linear modeling function $1 \mathrm{~m}$, the natural spline function ns, and the nonparametric bootstrapping function bootstrap (available within the resample library). Other functions and code were custom written. With some small changes, the scripts would also run under the Open Source system R.

Plots of input resistance over time were fit with cubic splines using ordinary least squares. Cubic splines are piecewise cubic polynomial functions that join smoothly at the breakpoints (or knots) where the cubics connect. Splines are easily constructed given the knot and boundary positions, have the capacity to approximate complex shapes in a parsimonious fashion, and can be fitted within the standard linear model framework using ordinary least squares. The usual tests of significance are appropriate if a normal error distribution can be assumed. For all of 
A

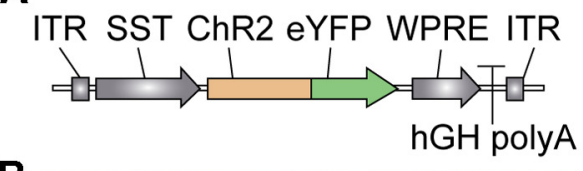

B
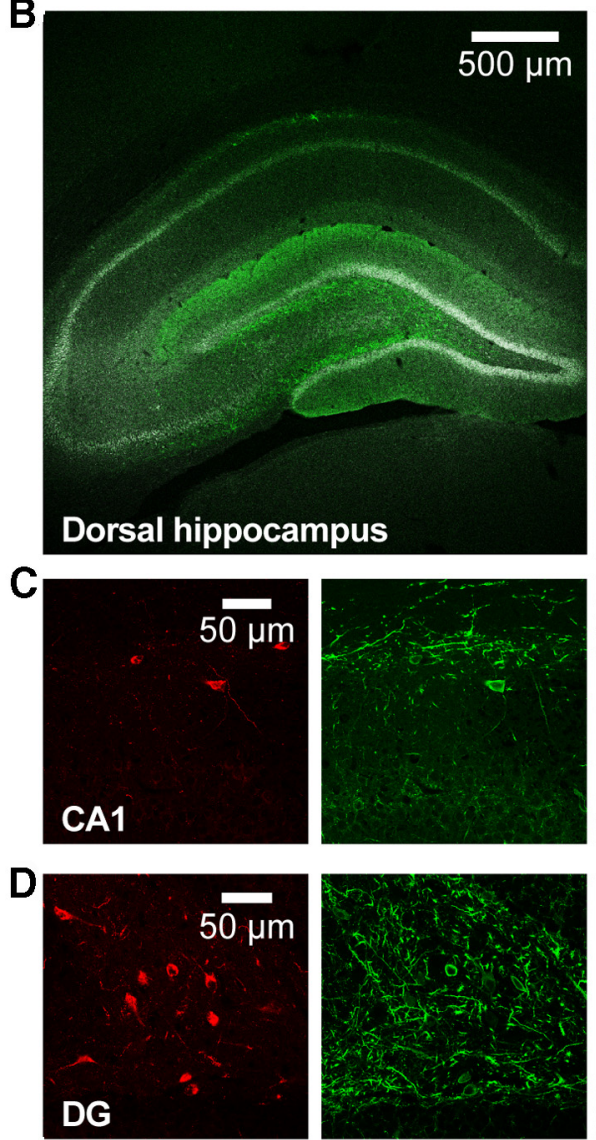

E
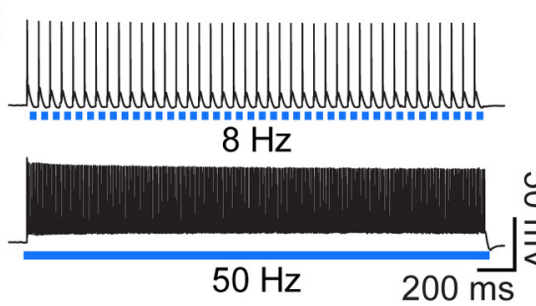
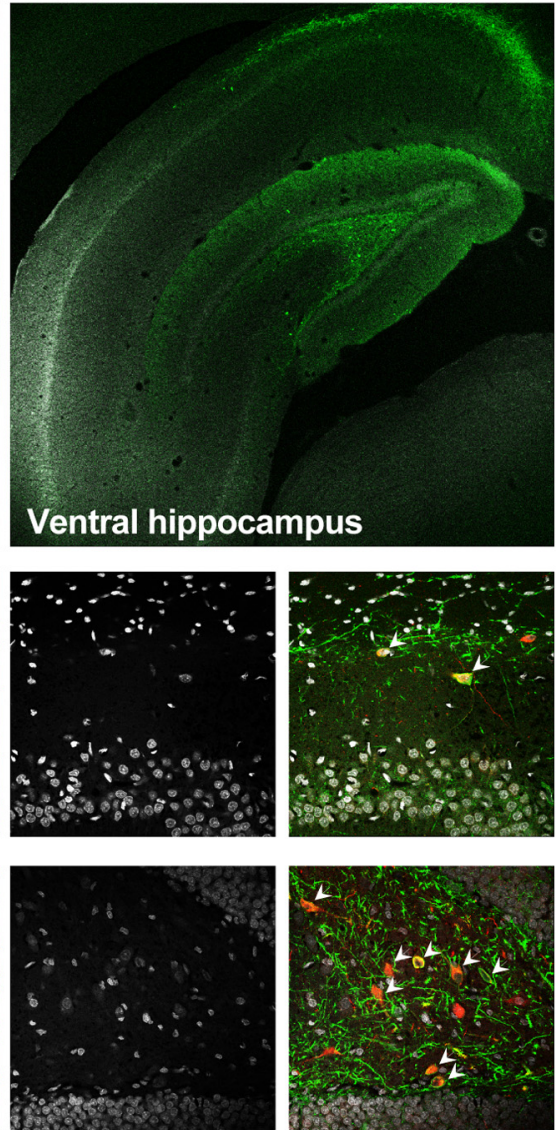

$\mathbf{F}$

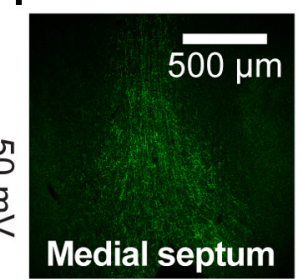

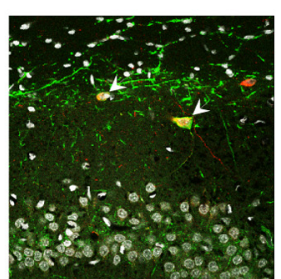
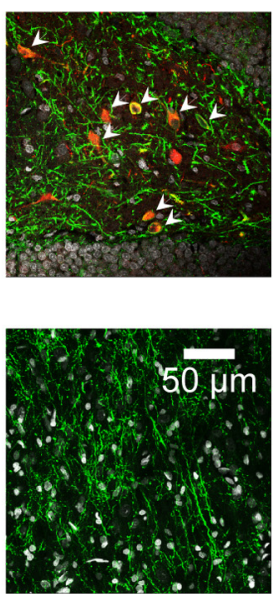

Figure 1. Optogenetic targeting of HS cells. $\boldsymbol{A}, \mathrm{AAV}$ vector design for specific targeting of SST-expressing neurons. $\boldsymbol{B}$, Viral expression (green) in dorsal and ventral hippocampus, with the pyramidal and granule cell layers highlighted by dense DAP staining (white). Expression was predominantly localized to stratum oriens (superficial to the pyramidal cell layer (DAPI; white) in CA1 and deep to it in CA3) as well as in the DG hilus. Minimal expression was seen in CA2. C, High-magnification view of CA1, demonstrating overlap (white arrowheads) between SST immunostaining (red) and virally expressed eYFP (green). DAPI (white) delineates the pyramidal cell layer. $\boldsymbol{D}$, High-magnification view of the DG, demonstrating overlap (white arrowheads) between SST immunostaining (red) and virally expressed eYFP (green). DAPI (white) delineates the granule cell layer. E, Sample current-clamp trace from a virally transduced cell, demonstrating high-fidelity light-evoked spiking at both 8 and $50 \mathrm{~Hz}$. F, ChR2-YFP-expressing axons in the medial septum, indicating successful targeting of HS cells, seen at low magnification (left) and high magnification (right).

the analyses, a natural cubic spline regression model was used (constraining the model function to be linear beyond the boundaries) with two internal knots. Given the knot positions, this model contains four unknown parameters (including the constant term that corresponds to the initial baseline level). Knots were adjusted manually to improve the fit.

To determine whether individual responses showed a statistically significant response, an $F$ test was performed to test whether the spline model was a significant improvement on a horizontal line. To correct for multiple such tests, a $p$ value of $\leq \sim 0.0004$ was set to achieve an approximate overall $5 \%$ level of significance. Since individual traces showed considerable random noise, parameters of interest were estimated from averaged population data, using the same cubic spline model fitted using weighted least squares. Note that cells were generally tested with 500 light pulses, and the population analysis excludes several responsive cells that were tested with fewer light pulses. Baseline input resistance levels varied across cells as expected, so individual traces were standardized by either subtracting, or dividing by, the average prestimulus resistance, before averaging across the traces. Therefore, both absolute and percentage changes in input resistance were estimated and are reported throughout. To determine confidence intervals (CIs) for the parameters of interest, a bootstrap approach was used to obtain a bootstrapped sampling distribution for each parameter. The model residuals were resampled (with replacement) 5000 times. On each occasion the bootstrap sample of residuals was added to the original fitted values to obtain a new bootstrapped trace, to which the natural spline model was refitted and the parameters estimated. This procedure resulted in a sample of 5000 bootstrap estimates for each parameter. The 95\% CI was taken to be the interval containing the central $95 \%$ of bootstrapped estimates, with $2.5 \%$ in each tail.

The same approach was used to determine the membrane potential decrease in response to stimulation. After standardization by subtraction of the baseline membrane potential, the sample averaged trace showed an obvious, seemingly linear, downward drift throughout the experimental period. An ad hoc detrending process was performed before model fitting, parameter estimation, and bootstrapping. A regression line was fitted to the prestimulus section of the average trace. Using the intercept and slope estimates, the line was extrapolated over the entire experimental period and then subtracted from the original averaged trace. The resulting trace was then analyzed in the usual way.

Reversal potential of the slow response was estimated as follows: The input resistance was estimated in each of the control and slowresponse conditions by the change in voltage divided by the injected current. From this the reversal potential of the slow response was estimated by assuming a parallel conductance model in which the slow response resulted from simple addition of an increased linear membrane conductance in parallel with the resting membrane conductance. Reversal potential was then estimated as that which would produce the change in membrane potential given the increase in conductance during the slow response. Correlation between the evoked hyperpolarization and input resistance decrease was calculated using a Spearman nonparametric correlation. Differences in occurrence of IPSCs and slow responses by cell type were assessed via a logistic regression interaction test. Correlation between IPSCs and slow responses within cells was calculated using a Fisher's exact test.

Immunohistochemistry. For thin-slice immunohistochemistry, rats were perfused transcardially 6-12 weeks postinjection with $\mathrm{PBS}$ followed by $4 \%$ paraformaldehyde (PFA). After an overnight postfix in PFA, brains were equilibrated in $30 \%$ sucrose in PBS for $\geq 72 \mathrm{~h}$. Forty- 
A

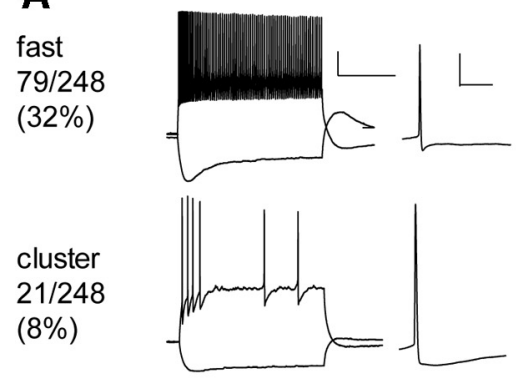

$21 / 248$

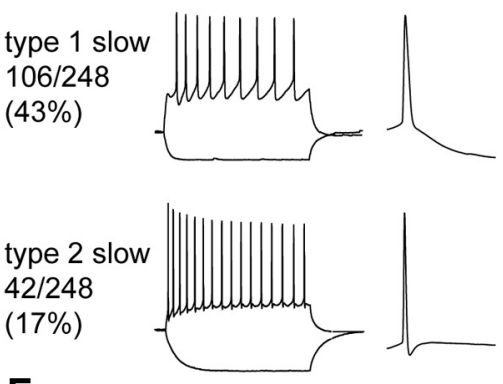

F

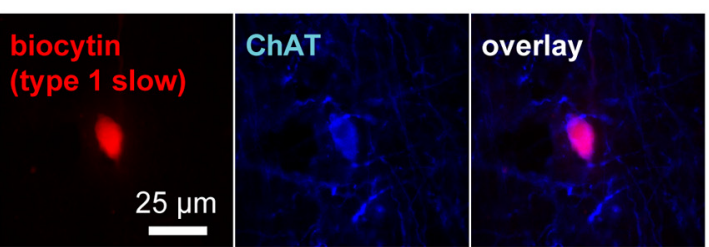

B
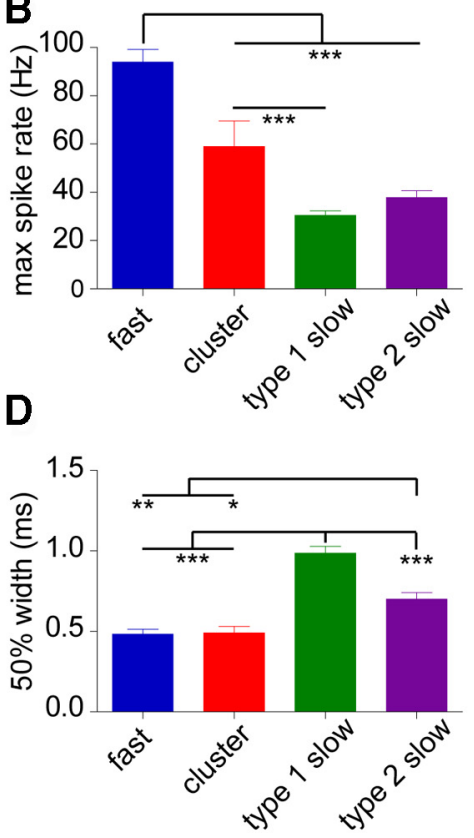

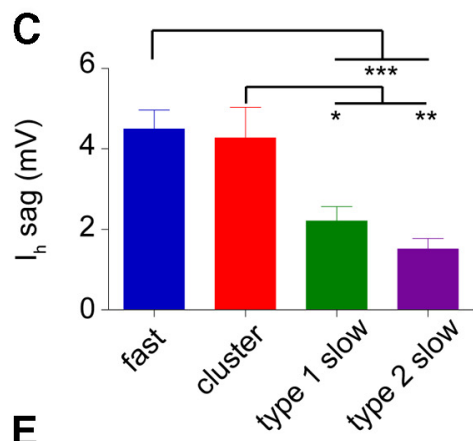

E

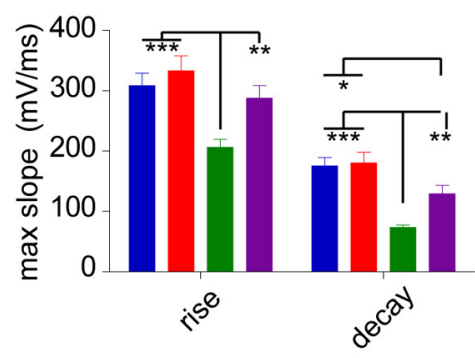

Figure 2. Classification of cell types in the adult medial septum. $\boldsymbol{A}$, Representative firing patterns and expanded single action potential traces for cells classified as fast-firing, cluster-firing, type 1 slow-firing, and type 2 slow-firing cells. For the cluster-firing cell, note the characteristic subthreshold membrane oscillations during firing pauses. For the type 1 slow-firing cell, note the significantly broader action potential. For the type 2 slow-firing cell, note the characteristic afterdepolarization of the action potential waveform. Scale bars: left, $20 \mathrm{mV}, 200 \mathrm{~ms}$; right, $20 \mathrm{mV}, 10 \mathrm{~ms}$. $\boldsymbol{B}$, Summary data for maximum spike rate, showing significantly greater maximal firing rate for fast-firing cells $(94 \pm 5 \mathrm{~Hz}, n=51)$ and cluster-firing cells $(59 \pm 11 \mathrm{~Hz}, n=13)$ compared with type 1 slow-firing cells $(30 \pm 2 \mathrm{~Hz}, n=55)$ and type 2 slow-firing cells ( $38 \pm 3 \mathrm{~Hz}, n=33$ ). C, Summary data for membrane potential sag reveals significantly larger sag for fast-firing cells (4.5 \pm 0.5 $\mathrm{mV}, n=38)$ and cluster-firing cells $(4.3 \pm 0.8 \mathrm{mV}, n=9)$ compared with type 1 slow-firing cells $(2.2 \pm 0.4 \mathrm{mV}, n=46)$ and type 2 slow-firing cells $(1.5 \pm 0.3 \mathrm{mV}, n=29)$. $\boldsymbol{D}$, Summary data for action potential half-width reveals that type 1 slow-firing cells had the largest half-width $(0.99 \pm 0.04 \mathrm{~ms}, n=31)$, followed by type 2 slow-firing cells $(0.71 \pm 0.04$ ms, $n=25)$, both significantly larger than for fast-firing cells $(0.48 \pm 0.03, n=21)$ and cluster-firing cells ( $0.49 \pm 0.04 \mathrm{~ms}, n=13)$. $\boldsymbol{E}$, Summary data for action potential rise slope (left) and decay slope (right, shown as $-\mathrm{mV} / \mathrm{ms}$ ). Type 1 slow-firing cells had the slowest rise ( $206 \pm 17 \mathrm{mV} / \mathrm{ms}, n=31)$ and decay $(73 \pm 4 \mathrm{mV} / \mathrm{ms}, n=31)$, followed by type 2 slow-firing cells $(288 \pm 21 \mathrm{mV} / \mathrm{ms}$ rise and $129 \pm 14 \mathrm{mV} / \mathrm{ms}$ decay, $n=25$ ). Fast-firing cells ( $309 \pm 21 \mathrm{mV} / \mathrm{ms}$ rise and $176 \pm 14 \mathrm{mV} / \mathrm{ms}$ decay, $n=21)$ and cluster cells $(333 \pm 25 \mathrm{mV} / \mathrm{ms} \mathrm{rise}$ and $181 \pm 18 \mathrm{mV} / \mathrm{ms} \mathrm{decay,} n=13)$ had significantly steeper slopes. Error bars represent SE; significance calculated using one-way ANOVA with Tukey's post hoc test. $\boldsymbol{F}$, Left, A patched type 1 slow-firing cell filled with biocytin (red) colabels with ChAT immunostaining (blue, left), whereas a patched fast-firing cell does not (right). Error bars represent SE. ${ }^{*}$, Significance $<0.05$; ${ }^{* *}$, significance $<0.01$; ${ }^{* *}$, significance $<0.001$.

micrometer-thick sections were obtained using a frozen microtome. Primary antibody incubations were performed overnight at $4^{\circ} \mathrm{C}$ in $3 \%$ normal donkey serum (NDS) and $0.3 \%$ Triton-X, with an antibody to SST (goat polyclonal; 1:500; Santa Cruz Biotechnology). Secondary antibody (1:500; Jackson Laboratories) was applied in 3\% NDS and $0.3 \%$ Triton-X for $1-3 \mathrm{~h}$ at room temperature. To quantify viral specificity for $\mathrm{SST}+$ neurons in SST-immunolabeled slices, eYFP + neurons were first identified based on native fluorescence (without further amplification), and presence or absence of SST expression was then assessed in those identified neurons. Slices were DAPI-stained $(1: 50,000)$ and coverslipped with polyvinyl alcohol and 1,4 diazabicyclo[2.2.2] octane in glycerine (Sigma-Aldrich). Images were obtained on a Leica confocal microscope using $5 \times, 20 \times$ (oil immersion), and $40 \times$ (oil immersion) objectives.

For biocytin labeling and post hoc immunohistochemistry in acute slices, biocytin (Invitrogen) was added to the pipette solution at $0.3 \%$ weight/volume. Each cell was imaged at low magnification after patching to identify its anatomical location, and slices were marked to indicate orientation. Thick slices were fixed overnight at $4^{\circ} \mathrm{C}$ in PFA, rinsed with PBS, and incubated for $2 \mathrm{~h}$ at room temperature in $60 \mu \mathrm{l}$ of Alexa Fluor 546 streptavidin conjugate (Invitrogen) added to $10 \mathrm{ml}$ of $1 \%$ Triton-X in PBS containing $0.2 \mathrm{~g}$ of BSA (Sigma-Aldrich). Primary antibody incu- bations were performed overnight at $4^{\circ} \mathrm{C}$ in $0.2 \%$ Triton- $\mathrm{X}$, with an antibody to ChAT (goat polyclonal; 1:200; Millipore). Secondary antibody (1:500; Jackson Laboratories) was applied in $0.2 \%$ Triton-X for $2 \mathrm{~h}$ at room temperature. Slices were DAPI-stained, coverslipped, and imaged as described above.

\section{Results}

Optogenetic targeting of the HS preparation and identification of septal cell types in slice

To optogenetically target HS neurons, we exploited the fact that they almost uniformly express the neuropeptide SST (Jinno and Kosaka, 2002; Gulyás et al., 2003), and we created an AAV (AAV2; UNC Vector Core) in which Channelrhodopsin-2 (ChR2) expression is under the control of the SST promoter (Tan et al., 2008). ChR2 was fused in-frame with eYFP to enable direct visualization of the cell bodies and axons of expressing neurons (Fig. 1A). Virus was injected in both dorsal and ventral hippocampus (Fig. $1 B$ ) with cell body expression in hippocampus observed between $\sim-3.2$ and $-5.2 \mathrm{~mm}$ relative to bregma on the anteroposterior axis; in more posterior (ventral) hippocampus, 
A
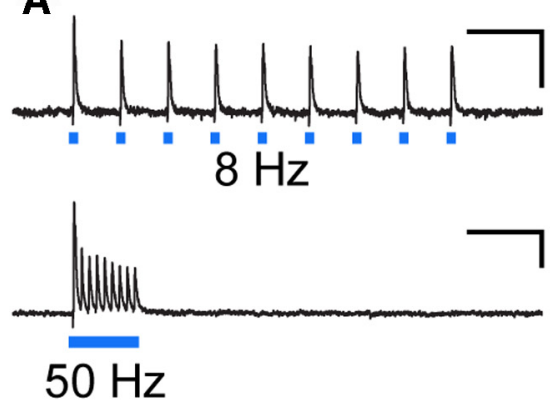

B
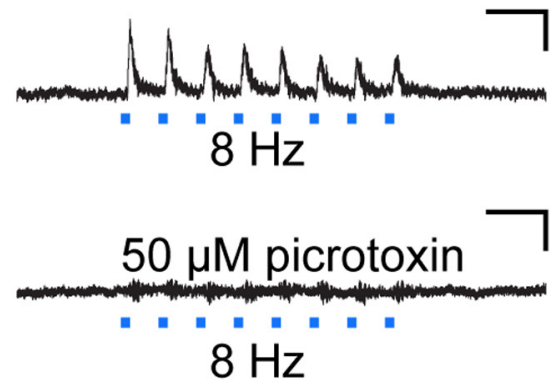
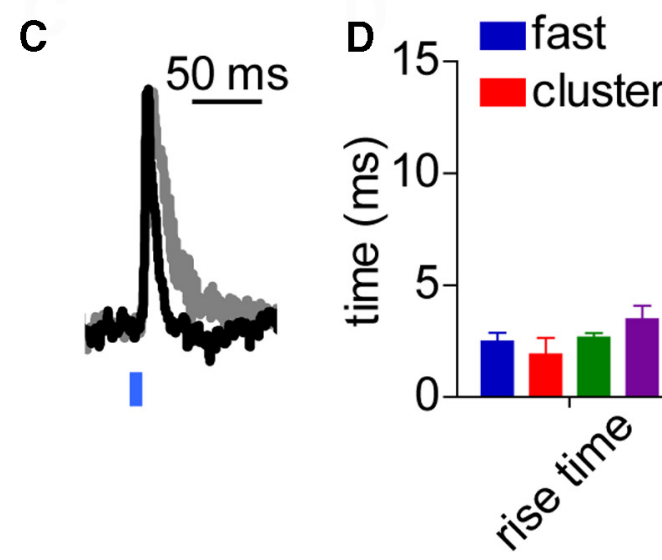

Figure 3. Optogenetically evoked IPSCs in medial septum in response to stimulation of HS fibers. Cells were held in voltage clamp at $-40 \mathrm{mV}$ for all IPSC recordings. $A$, GABA(A)-receptor-mediated IPSCs in a fast-firing cell, evoked by $5 \mathrm{~ms}$ blue light pulses delivered at $8 \mathrm{~Hz}$ (above) or $50 \mathrm{~Hz}$ (below). Blue bars indicate light stimuli. Scale bars: 50 pA, $200 \mathrm{~ms}$. B, Sample trace illustrating inhibition of IPSCs by application of $50 \mu \mathrm{m}$ picrotoxin. A complete block was seen in four of four cells tested. Scale bars: $20 \mathrm{pA}, 200$ ms. C, Comparison of optogenetically evoked IPSCs in the fast-firing cell from $\boldsymbol{A}$ and $\boldsymbol{B}$ (black trace) and a type 2 slow-firing cell (gray trace) to illustrate differences in IPSC kinetics. Traces are normalized to peak and aligned to the light stimulus. D, Summary data showing rise time, decay time constant, and half-width of evoked IPSCs in the four cell types: fast firing $(n=18)$, cluster firing $(n=3)$, type 1 slow firing $(n=8)$, and type 2 slow firing $(n=8)$. Tukey's post hoc tests revealed no significant differences in rise time or half-width, but the decay time constant for type 2 slow-firing cells (10.3 $\pm 1.1 \mathrm{~ms}$ ) was significantly larger than that of both fast-firing $(5.8 \pm 0.6 \mathrm{~ms})$ and cluster-firing $(3.5 \pm 0.4 \mathrm{~ms})$ cells. Error bars represent SE. ${ }^{* *}$, Significance $<0.01$.

follow 8 and $50 \mathrm{~Hz}$ light pulses $(1.28 \pm$ 0.25 spikes per light pulse at $8 \mathrm{~Hz} ; 1.01 \pm$ 0.00 spikes per light pulse at $50 \mathrm{~Hz} ; n=8$; Fig. $1 E$ ), with the occasional multiple spikes consistent with previous reports of firing evoked by ChR2(H134R) (Mattis et al., 2012). Since HS neurons constitute only approximately one-third of all SST+ hippocampal cells (Jinno and Kosaka, 2002), we confirmed that the HS cells were among the SST cells targeted by the virus by verifying the presence of eYFP+ axons in the medial septum (Fig. $1 F$ ).

To investigate the synaptic effects of the HS projection on septal cells, we performed whole-cell recordings in an acute medial septum slice preparation. Extensive prior literature has focused on characterizing septal cell types based on their physiological properties (Markram and Segal, 1990; Gorelova and Reiner, 1996; Morris et al., 1999; Knapp et al., 2000; Manseau et al., 2005), which have been mapped onto their immunohistochemical characteristics (Sotty et al., 2003). In general agreement with those studies, we found cells resembling previously described fast-firing (putative GABAergic), cluster-firing (putative glutamatergic), and slow-firing (putative cholinergic) cells; we further divided slow-firing cells into two types based on differences in action potential waveform (Fig. $2 A$ ).

The cell types differed significantly by maximum firing rate (Fig. $2 B$ ): fast-firing cells had the highest rate $(94 \pm 5 \mathrm{~Hz}, n=$ 51), followed by cluster-firing cells ( $59 \pm$ $11 \mathrm{~Hz}, n=13)$, followed by both subtypes of slow-firing cells (type 1 slow firing:

expression was generally stronger superficially, as shown. Within the hippocampal subfields, strong viral expression was seen in stratum oriens of CA1 and CA3 and in the hilus of the dentate gyrus (DG), minimal viral expression was observed in CA2, and no viral expression was observed in cell bodies in subiculum or other brain regions. Expression was predominantly localized to the stratum oriens in CA1 and CA3, and to the hilus of the DG. Virus expression overlapped well with SST immunostaining in both CA1 (Fig. 1C) and DG (Fig. 1D), with $86 \%$ of expressing cells staining positive for SST (609 of 709 cells across three animals). Of the eYFP+ neurons that were SST,$- 70 \%$ (70 of 100 cells) were located in the granule cell layer (in the DG) or the pyramidal cell layer (in CA1 or CA3); the specificity among nonprincipal cells was $95 \%$ (609 of 639 cells).

To assess ChR2 functionality, we patched virus-expressing cells in acute hippocampal slices and demonstrated robust photocurrents (818 $\pm 155 \mathrm{pA} ; n=9)$. To establish that light stimulation could drive action potentials in expressing cells at a rate comparable to the upper bounds of spontaneous firing rates of HS cells as measured in vivo (Jinno et al., 2007), we first verified that expressing cells were all capable of following a prolonged ( 5 s) train of both 8 and $50 \mathrm{~Hz}$ current pulses $(1.03 \pm 0.03$ spikes per current pulse at $8 \mathrm{~Hz} ; 1.00 \pm 0.00$ spikes per current pulse at 50 $\mathrm{Hz} ; n=5$ ), and then confirmed that those cells could similarly
$30 \pm 2 \mathrm{~Hz}, n=55$; type 2 slow firing: $38 \pm 3 \mathrm{~Hz}, n=33$ ). Membrane potential sag was measured from hyperpolarizations to $\sim-80$ to $-90 \mathrm{mV}$. Consistent with previous reports (Morris et al., 1999; Sotty et al., 2003), fast-firing cells had significantly larger membrane potential sag than both subsets of slow-firing cells (fast-firing cells: $4.5 \pm 0.5 \mathrm{mV}, n=38$; type 1 slow-firing cells: $2.2 \pm 0.4 \mathrm{mV}, n=46$; type 2 slow-firing cells $1.5 \pm 0.3 \mathrm{mV}$, $n=29)$; cluster-firing cells similarly had larger sag $(4.3 \pm 0.8 \mathrm{mV}$, $n=9$; Fig. $2 C$ ). The action potential waveforms also differed significantly between cell types, quantified by measurements of $50 \%$ spike width (Fig. 2D) and maximum rise and decay slopes (Fig. 2E). Fast-firing and cluster-firing cells had spikes with the narrowest widths and the largest maximum rise and decay slopes, as expected, and type 2 slow-firing cells also had spikes that were significantly narrower and steeper than those of type 1 slow-firing cells.

Based on their slow and broad waveform, we conclude that type 1 slow-firing cells are the previously described cholinergic cells of the MSDB (Markram and Segal, 1990; Gorelova and Reiner, 1996; Morris et al., 1999; Sotty et al., 2003), but the neurochemical identity of the type 2 slow-firing cells was less clear. To investigate this, we filled patched septal cells of both subtypes with biocytin, postfixed the acute slices, and stained for ChAT. Type 1 slow-firing cells were confirmed to be ChAT-positive ( 7 of 
A

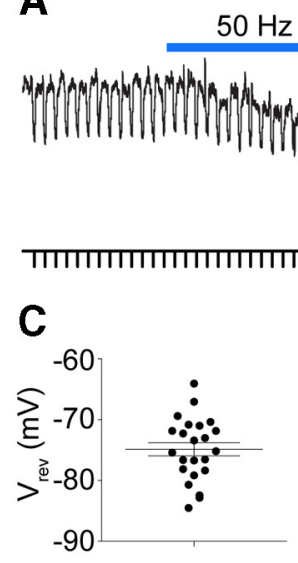

all responders

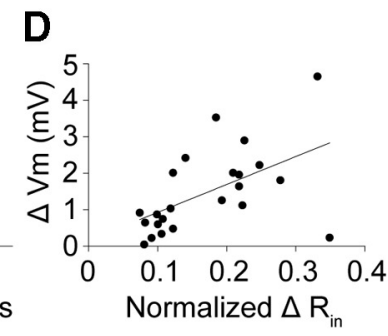

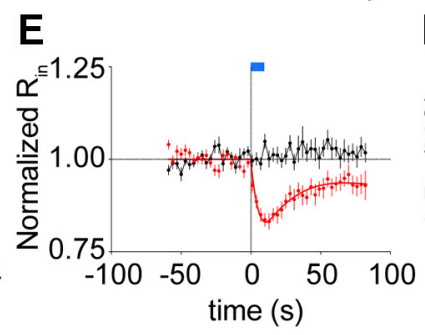

B
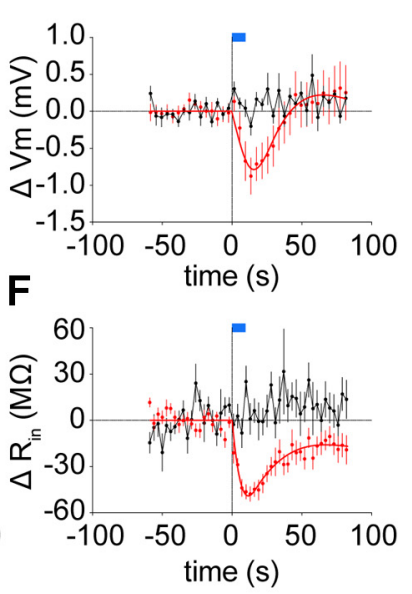

Figure 4. Prolonged stimulation leads to hyperpolarization and decreased input resistance in a subset of cells. Cells were recorded in current clamp between -60 and $-65 \mathrm{mV}$. Brief current injections (10-25 pA) were given at a rate of $1-2 \mathrm{~Hz}$ to monitor input resistance. $A$, Current-clamp trace illustrating slow-onset and persistent hyperpolarization and decreased input resistance in response to pulses of blue light delivered at $50 \mathrm{~Hz}$. $\boldsymbol{B}$, Summary membrane potential data of all responsive cells ( $n=24$, red), illustrating that on average responding cells have a small light-evoked decrease in membrane potential. Data were binned $(n=3)$ and linearly detrended to correct for a small $(\sim 1 \mathrm{mV})$ hyperpolarizing drift over the course of the recording. A matched control group of the same number of nonresponding cells patched on the same days was plotted for comparison ( $n=24$, black). $C$, Estimated reversal potentials of the response ranged from -64 to $-85 \mathrm{mV}$ (mean, $-74.9 \pm 1.1 \mathrm{mV}, n=23)$. $\boldsymbol{D}$. Hyperpolarization and normalized input resistance decrease were highly correlated $\left(\rho_{(21)}=0.57, p=0.0043\right)$. Input resistance was averaged across all responsive cells with a statistically significant response $(n=24$, red), binned $(n=3)$, and plotted over time to show either the normalized $(\boldsymbol{E})$ or absolute $(\boldsymbol{F})$ decline in input resistance. For plots over time $(\boldsymbol{B}, \boldsymbol{E}, \boldsymbol{F})$, error bars represent $\mathrm{SE}$.

9 clearly colabeled with ChAT), in contrast to several fast-firing cells used as a negative control (Fig. $2 F$ ). However, type 2 slowfiring cells were more difficult to assess by this method ( 3 of 3 ambiguous staining). We therefore took an alternative approach, targeting known cholinergic cells by injecting a Cre-dependent AAV into the medial septum of transgenic ChAT::Cre rats (Witten et al., 2011) and recording from virus-expressing cells in adult rats. Among these known cholinergic cells, 79\% (15 of 19) were type 1 slow-firing cells and $21 \%$ (4 of 19) were type 2 slow-firing cells; none were fast-firing or cluster-firing cells. Given the known high specificity of this transgenic rat line (Witten et al., 2011), we conclude that cholinergic cells can have either type 1 or type 2 slow-firing characteristics.

Fast and slow responses in septal cells in response to HS input Postsynaptic GABAergic responses were assayed by holding neurons at $-40 \mathrm{mV}$ in voltage clamp and stimulating the slice with short trains of light pulses, sourced by a blue laser $(473 \mathrm{~nm})$. A subset of neurons (53 of 225 cells; 24\%) responded with IPSCs, which could be evoked effectively at both 8 and $50 \mathrm{~Hz}$ (Fig. 3A). These responses appeared to be GABA(A) mediated, and indeed were completely abolished by the addition of picrotoxin $(50 \mu \mathrm{M})$ in 4 of 4 cells, including fast-firing, type 1 slow-firing, and type 2 slow-firing cell types (Fig. 3B). The kinetics of these light-evoked IPSCs varied by cell type, with those in type 2, but not type 1 , slow-firing cells having significantly greater decay times than those in fast-firing and cluster-firing cells (Fig. 3C,D).

To investigate whether hippocampal input could affect the membrane properties of septal cells, we recorded from septal neurons in current clamp while administering serial smallcurrent injections (5-25 pA) to monitor input resistance. We used prolonged pulse trains (500 pulses) in order to maximize our ability to detect and characterize these postsynaptic changes. In response to $50 \mathrm{~Hz}$ stimulation with blue light, we observed a slow-onset decrease in input resistance, corresponding to a small membrane hyperpolarization, in a subset of cells (Fig. 4A). To identify cells that had a statistically significant response to stimulation, we plotted calculated input resistance over time, fit the data, and tested whether the fit was significantly better than that of a horizontal line (see Materials and Methods for further description). Using this approach, we identified 25 cells that responded to stimulation with a significant decrease in input resistance (of a total of 133 cells; 19\%).

As a population, the responsive cells demonstrated a small but significant slow-onset hyperpolarization $(0.78 \mathrm{mV}$; $95 \% \mathrm{CI}$, $0.72-0.83 \mathrm{mV}$; Fig. $4 B$ ). Even though the extent of hyperpolarization was quite modest, we were able to estimate the reversal potential of the evoked current by using a simple parallel conductance model (see Materials and Methods). Estimated reversal potentials ranged from mildly to strongly hyperpolarizing (range, -64 to $-85 \mathrm{mV}$; Fig. 4C), consistent with expectations of a potassiumdominated conductance. Since hyperpolarization magnitude was highly correlated with decrease in input resistance $(p=0.0043$; Fig. $4 D$ ), which was larger and therefore easier to quantify, we focused on input resistance for the remainder of the analysis.

To quantify the magnitude and kinetics of the input resistance decrease, we averaged across all responsive cells using either baseline-divided (Fig. $4 E$ ) or baseline-subtracted (Fig. $4 F$ ) input resistance measurements and fit the same model to the averaged population data as to the individual traces (see Materials and Methods). The average response magnitude across responsive cells was a normalized input resistance decrease of $16.8 \%(95 \%$ CI, 15.3-18.2\%) and an absolute decrease of $48.4 \mathrm{M} \Omega(95 \% \mathrm{CI}$, $44.0-52.8 \mathrm{M} \Omega$ ). For both fits the minimum input resistance occurred $\sim 12 \mathrm{~s}$ after the onset of light stimulation. No net effect on resting potential or input resistance was seen in a control group of a subset of nonresponsive cells, matched for number of cells and patched on the same days (Fig. $4 B, E, F$ ).

We next sought to explore the mechanism underlying this slow response. As a necessary positive control, we first confirmed that the response could be reliably repeated across multiple trials of light stimulation (Fig. 5A), delivered with $\geq 5$ min of recovery 


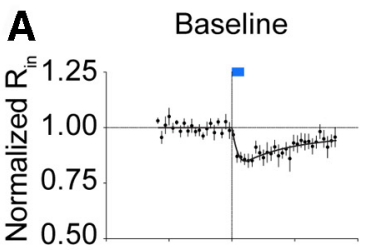

\section{B}

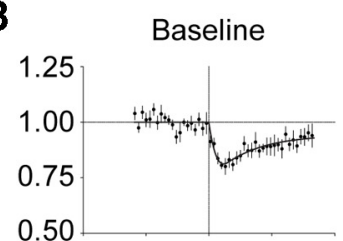

C

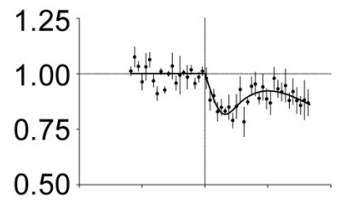

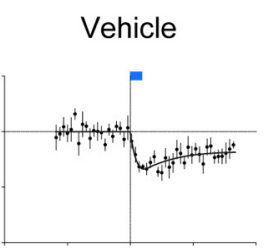

Barium

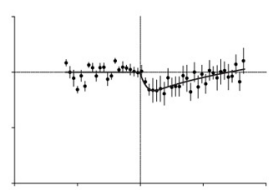

Cyclosomatostatin

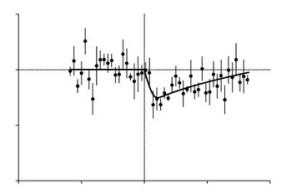

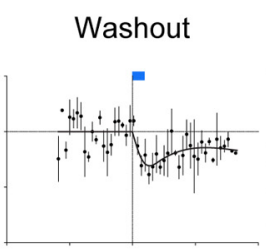

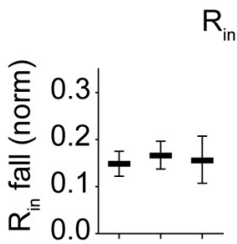

$\mathrm{R}_{\text {in }}$ Fall

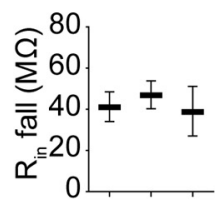

D

Baseline

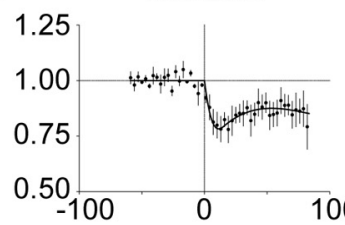

Prochlorperazine
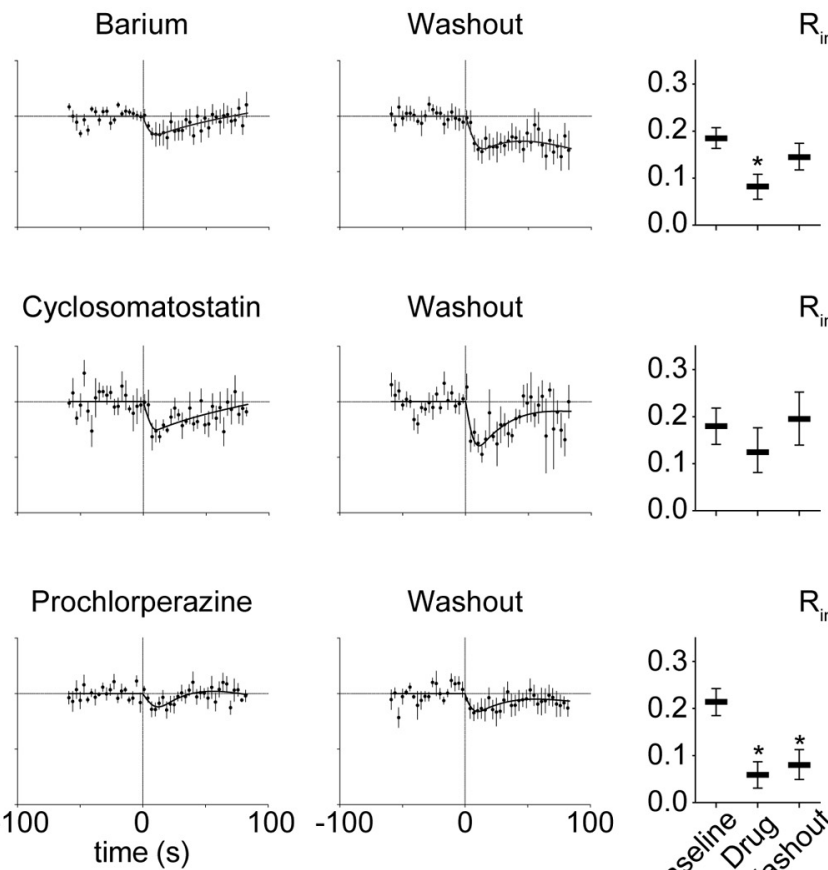

$\mathrm{R}_{\text {in }}$ Fall

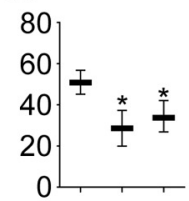

\section{Washout}
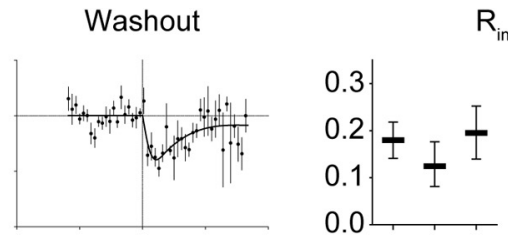

$\mathrm{R}_{\text {in }}$ Fall

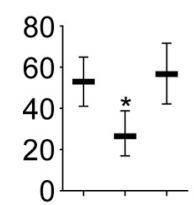

E

E

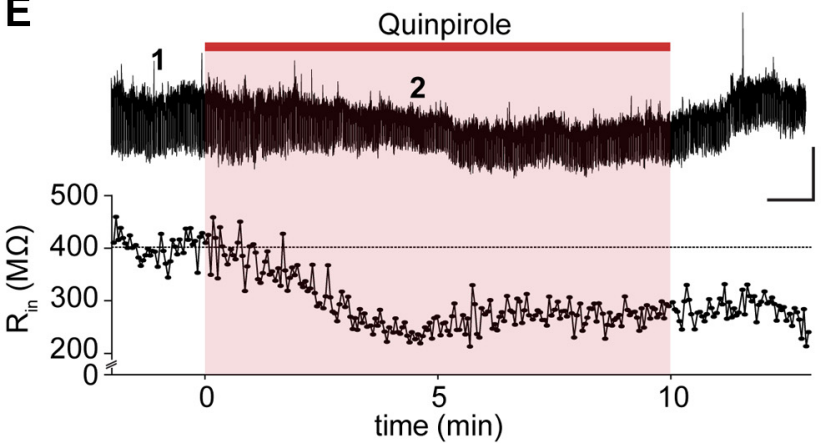

Washout
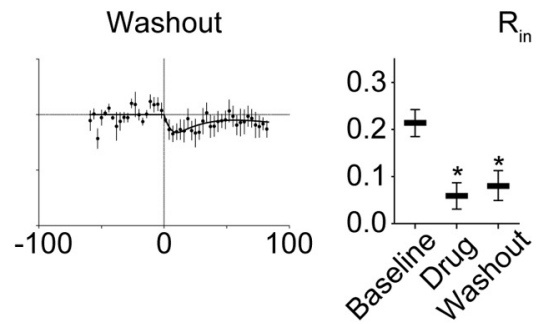

$\mathrm{R}_{\text {in }}$ Fall
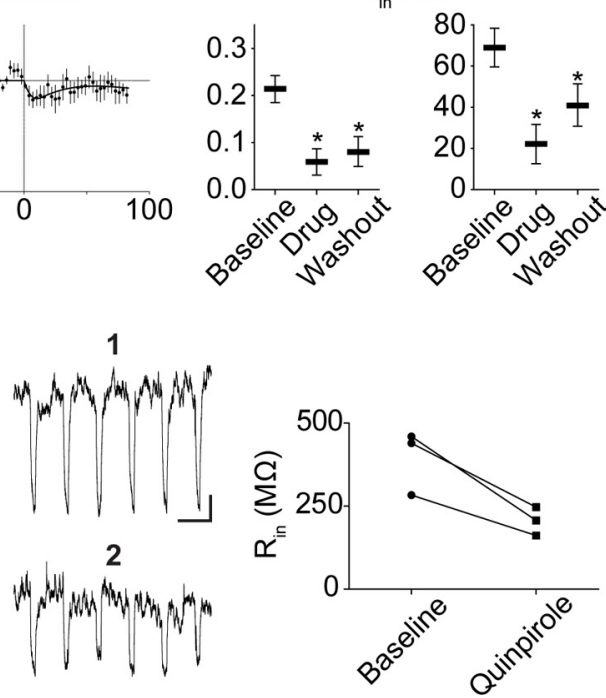

Figure 5. Mechanism of the slow response. $A-D$, Normalized input resistance $\left(R_{\text {in }}\right)$ in response to 500 pulses of $50 \mathrm{~Hz}$ light delivered at baseline, with drug application, and after wash-out. $R_{\text {in }}$ in each case was averaged across cells that are responsive at baseline, binned $(n=3)$, and plotted over time (columns 1-3). The population data were fit with splines to determine the relative and absolute magnitude of the input-resistance fall (columns 4 and 5 , respectively). $A, R_{\text {in }}$ was stable to repetitive $50 \mathrm{~Hz}$ light delivery $(n=7,7$, and 3 , respectively). $\boldsymbol{B}$, Barium, a GIRK channel antagonist, partially blocked the response $(n=7)$. Normalized $R_{\text {in }}$ fell significantly from $18.5 \%(95 \% \mathrm{Cl}, 16.3-20.8 \%)$ at baseline to $8.2 \%(95 \% \mathrm{Cl}, 5.5-10.9 \%)$ with barium, and absolute $R_{\text {in }}$ fell significantly from $50.9 \mathrm{M} \Omega(95 \% \mathrm{Cl}, 45.1-56.8 \mathrm{M} \Omega)$ at baseline to $28.6 \mathrm{M} \Omega(95 \% \mathrm{Cl}, 20.0-37.3 \mathrm{M} \Omega)$ with barium. C, Cyclosomatostatin, a nonspecific SSTR antagonist, partially blocked the response $(n=$ 4). Normalized $R_{\text {in }}$ trended down from $18.0 \%(5-95 \% \mathrm{Cl}, 14.8-21.2 \%)$ at baseline to $12.5 \%(5-95 \% \mathrm{Cl}, 8.8-16.9 \%)$ with cyclosomatostatin, while the absolute $R_{\text {in }}$ fell significantly from $53.0 \mathrm{M} \Omega$ $(5-95 \% \mathrm{Cl}, 42.8-63.1 \mathrm{M} \Omega)$ at baseline to $26.5 \mathrm{M} \Omega(5-95 \% \mathrm{Cl}, 18.3-36.7 \mathrm{M} \Omega)$ with cyclosomatostatin. $D$, Prochlorperazine, a D2 receptor antagonist, significantly blocked the response $(n=5)$. Normalized $R_{\text {in }}$ fell significantly from $21.4 \%(5-95 \% \mathrm{Cl}, 19.0-23.8 \%)$ at baseline to $5.9 \%(5-95 \% \mathrm{Cl}, 3.5-8.2 \%)$ with prochlorperazine, and absolute $R_{\text {in }}$ significantly fell from $69.0 \mathrm{M} \Omega(5-95 \%$ $(\mathrm{Cl}, 61.2-76.8 \mathrm{M} \Omega)$ at baseline to $22.2 \mathrm{M} \Omega(5-95 \% \mathrm{Cl}, 14.2-30.2 \mathrm{M} \Omega)$ with prochlorperazine. $E$, Sample current-clamp trace (top left) illustrates slow-onset hyperpolarization and decreased $R_{\text {in }}$ in response to quinpirole (red line), a D2-receptor agonist (scale bar: $5 \mathrm{mV}, 1 \mathrm{~min}$ ). $R_{\text {in }}$ for that trace was calculated, binned $(n=3)$, and plotted over time (bottom left). Voltage deflections in response to current injections at baseline (1) and after quinpirole administration (2), at the times indicated on the full trace on the left (scale bar: $1 \mathrm{mV}, 1 \mathrm{~s}$ ). Absolute $R_{\text {in }}$ for all three responsive cells at baseline and in response to quinpirole demonstrates large fall in each case (plot on right). For $\boldsymbol{A}-\boldsymbol{E}$, error bars on the plots over time (columns $1-3$ ) represent $S E$, whereas error bars on the summary plots (columns $4-5$ ) represent 5-95\% Cls. Significance $\left({ }^{*}\right.$ ) was defined as nonoverlapping $95 \%$ Cls, which are generated by bootstrapping.

in between. In absolute terms, input resistance recovered fully between stimulations (second stimulation baseline: $96.8 \pm 7.8 \%$ of first stimulation baseline; $n=7$ ). Since the activation of potassium channels, including GIRK channels, could result in decreased input resistance and hyperpolarization, we tested whether the GIRK chan- nel antagonist barium (Lesage et al., 1995) would block the response and found a $\sim 50 \%$ inhibition (Fig. $5 B$ ).

Having already established that HS projection stimulation releases GABA (giving rise to the GABA(A)-mediated IPSCs described above; Fig. 3), we hypothesized that the slow response 
may be mediated by $\mathrm{GABA}(\mathrm{B})$ receptors on responsive cells. However, the GABA(B) receptor antagonist CGP 55845 hydrochloride showed no evidence of even a partial block ( $n=2$, data not shown). HS cells also express SST (Jinno and Kosaka, 2002; Gulyás et al., 2003), a neuropeptide known to signal through GIRK channels (Mihara et al., 1987; Sims et al., 1991) and to evoke similar inhibitory responses in other brain regions (Twery and Gallagher, 1989; Greene and Mason, 1996; Schweitzer et al., 1998), so we hypothesized that the response might be due to SST released by optogenetic stimulation from HS terminals. Indeed, we were able to achieve a partial block $(\sim 30 \%)$ with the nonspecific SSTR antagonist cyclosomatostatin (5 $\mu \mathrm{M}$; Fig. $5 C$ ).

Since the SST2A receptor is the subtype most abundantly expressed on somata in the adult rat medial septum (Thoss et al., 1995; Fehlmann et al., 2000), we next assessed whether specifically inhibiting the SST2A receptor could antagonize the response. However, the specific SST2A receptor antagonist cyanamid $(1 \mu \mathrm{M})$ had no significant effect on the response (data not shown). In a separate line of experiments, we tested whether octreotide, a SST2AR agonist, would mimic the response. However, of 27 cells tested with octreotide, only two (7\%) responded with an unambiguous decrease in input resistance (data not shown), versus $19 \%$ responding to optogenetic stimulation (whereas we would expect a comparatively larger proportion of cells to respond to agonist application given that the optogenetic stimulation is prone to false-negative results). Notably, among the cells that showed no response to octreotide were two cells with a confirmed response to optogenetic stimulation. Thus we conclude that the slow response is not mediated by the somatically expressed SST2AR, but may rather be partially mediated by a different SSTR subtype, expressed either on the somata of responsive cells or on terminals of upstream cells.

We next tested the hypothesis that our stimulation may be recruiting downstream network activity that could act via other receptor types to give rise to the observed response. Cells in the medial septum express many additional receptor types, including muscarinic acetylcholine receptors (Van der Zee and Luiten, 1994; Levey et al., 1995), Al adenosine receptors (Rivkees et al., 1995), D2 dopamine receptors (Weiner et al., 1991), neuropeptide $\mathrm{Y}$ receptors (Wolak et al., 2003), and $\mu$-opioid receptors (Mansour et al., 1994), all of which have previously shown to give rise to similar slow-timescale inhibitory responses. We performed a series of experiments using mixtures of antagonists to different combinations of these receptors $(n=1-2$ per mixture, data not shown; see Materials and Methods for details), and discovered that among them the response was uniquely blocked by the D2 receptor antagonist prochlorperazine $(10 \mu \mathrm{m})$, which profoundly inhibited the light-evoked input-resistance decrease (Fig. 5D), from $21.4 \%(5-95 \%$ CI, $19.0-23.8 \%)$ at baseline to $5.9 \%$ (5-95\% CI, 3.5-8.2\%) after prochlorperazine wash-on. To corroborate this result, we selectively patched identified cholinergic cells in ChAT::Cre rats and bath-applied the D2 receptor agonist quinpirole $(10 \mu \mathrm{m})$. We identified the characteristic slow response in three of six cells with highly significant inputresistance drop ranging from 43 to $55 \%$ (Fig. $5 E$ ).

\section{Frequency dependence and cell type divergence of HS signaling}

Since HS cells are known to fire at either high or low frequency, depending on the hippocampal state (Jinno et al., 2007), we next assessed whether this slow response was more readily evoked by the same number of pulses delivered at either 8 or $50 \mathrm{~Hz}$. Among cells that had a statistically significant decrease in input resistance to $50 \mathrm{~Hz}$ stimulation, seven of eight had a smaller or nonsignificant response to the same total number of pulses delivered at 8 $\mathrm{Hz}$, as illustrated by a sample trace (Fig. $6 \mathrm{~A}$ ). No cells that failed to respond to $50 \mathrm{~Hz}$ stimulation responded significantly to $8 \mathrm{~Hz}$ stimulation. The data from responsive cells was again normalized, averaged, fit using the cubic spline model, and then bootstrapped to enable a statistical comparison between the magnitudes of the response in the two conditions (Fig. 6B). Indeed, $50 \mathrm{~Hz}$ stimulation led to a statistically larger fall in input resistance, both in relative (16.1 vs $3.3 \%$; Fig. $6 C$ ) and absolute ( 48.0 vs $14.6 \mathrm{M} \Omega$; Fig. $6 D$ ) terms. We also noted that the kinetics of the response differed between the two conditions: the $50 \mathrm{~Hz}$ stimulation response peaked at $14 \mathrm{~s}$ compared with $41 \mathrm{~s}$ for $8 \mathrm{~Hz}$ (Fig. 6E).

Finally, we examined the distribution of cell types among the cells that exhibited fast (GABAergic) and/or slow responses. We found that the two responses were statistically uncorrelated on a per-cell basis $(p=0.78)$. In fact, of the 133 cells tested for both IPSCs and slow responses, only four exhibited both. We further examined the two responses by noting the location of patched cells within the septum that exhibited one or both response types, and observed no obvious relationship between location within the septum and either cell type or response (Fig. 7A).

Of the total number of patched septal cells ( 255 cells), almost all (248) could be classified as one of the four cell types described above (Fig. 2). Of these classified cells, 31\% (79 cells) were fast 


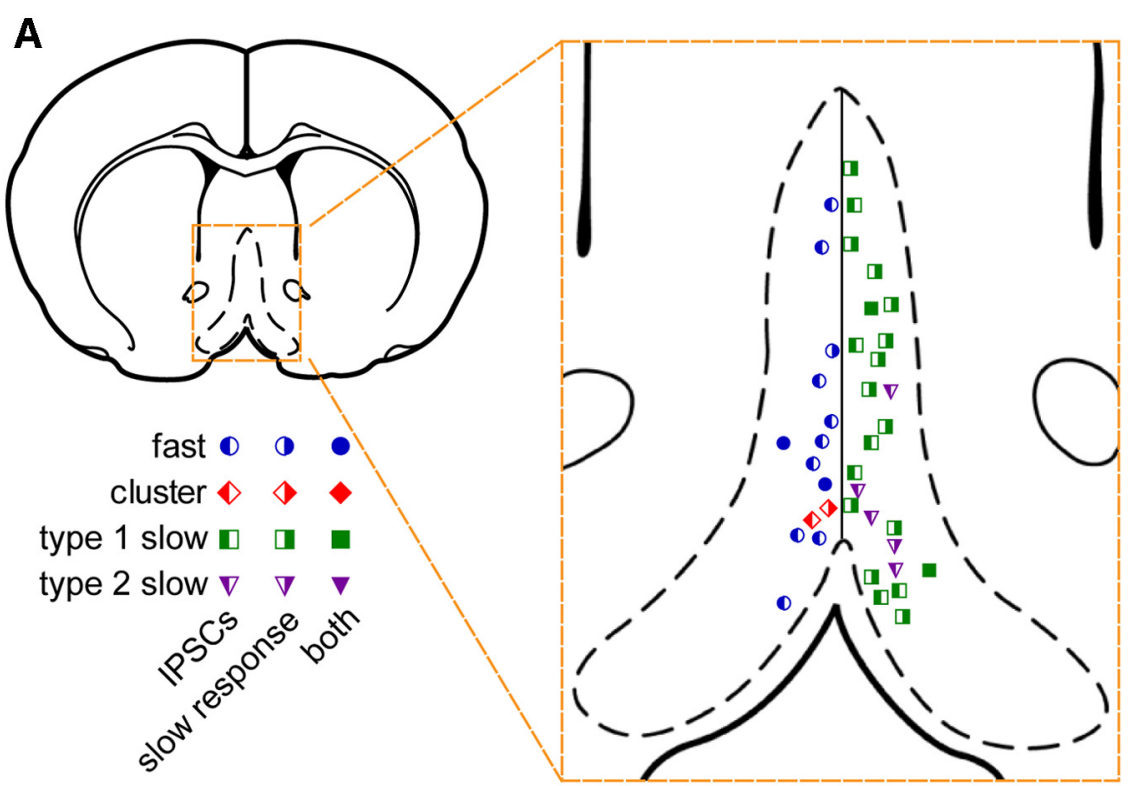

B

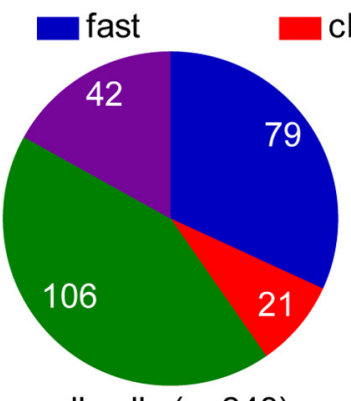

cluster type 1 slow

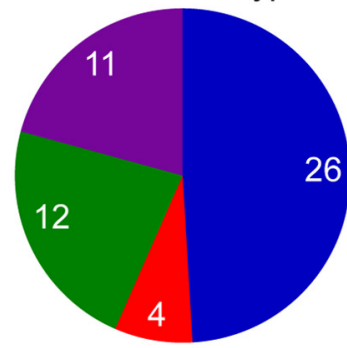

IPSCs $(\mathrm{n}=53)$

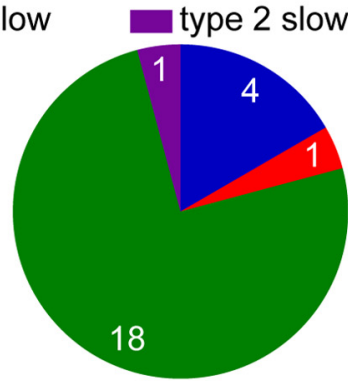

slow response $(n=24)$ all cells $(n=248)$

C

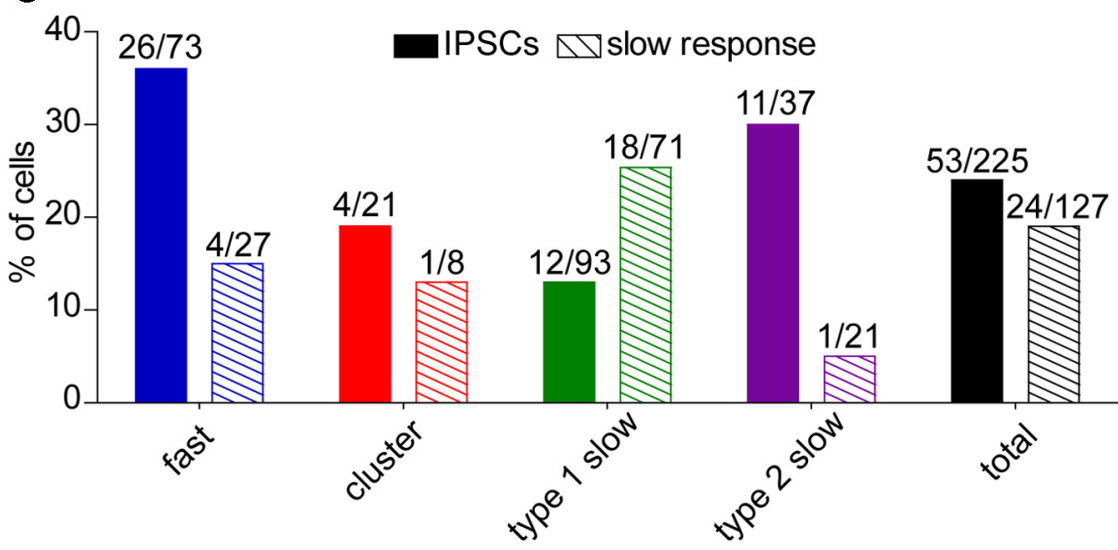

Figure 7. IPSCs and slow responses are seen in independent populations of septal cells. $A$, Locations of patched septal cells with IPSCs and/or slow responses. Blue circles indicate fast-firing cells, red diamonds indicate cluster-firing cells, green squares indicate type 1 slow-firing cells, and purple triangles indicate type 2 slow-firing cells. Symbols filled on the left indicate IPSCs only, symbols filled on the right indicate slow-response only, and entirely filled symbols indicate both response types. For display purposes, fast-firing and cluster-firing cells are indicated on the left and type 1 and type 2 slow-firing cells are indicated on the right, although locations of all cell types were in fact symmetric around the midline. $\boldsymbol{B}$, Pie charts showing distribution of the four characterized cell types: fast (blue), cluster (red), type 1 slow (green), and type 2 slow (purple). Left, Distribution of all cells that could be classified by cell type ( $n=248)$. Center, Distribution of all cells that had light-evoked IPSCs $(n=53)$. Right, Distribution of all cells that had light-evoked input resistance decrease in response to prolonged $50 \mathrm{~Hz}$ stimulation $(n=24)$. Note that fast cells disproportionately respond with IPSCS, while type 1 (but not type 2) slow cells disproportionately exhibit the slow response. On each pie chart, the numbers indicate the $n$ for each cell type. C, Percentage of cells exhibiting IPSCs and slow responses for each cell type and for all cells, illustrating that fast-firing and type 2 slow-firing cells are more likely to have IPSC responses, whereas type 1 slow-firing cells are more likely to have slow responses. Responses were found to be highly variable by cell type $(p=0.0024$ with a logistic regression interaction test). Numbers above each bar indicate the number of positive cells divided by the total number of assayed cells in each case.

firing, $8 \%$ (21 cells) were cluster firing, $42 \%$ (106 cells) were type 1 slow firing, and $17 \%$ ( 42 cells) were type 2 slow firing (Fig. $7 B$, left). We found that the distribution of cell types with IPSCs to light stimulation had an increased representation of fastfiring cells, which constituted nearly half of the GABAergic responses (Fig. $7 B$, center). This is in agreement with previous anatomic studies showing that the HS projection preferentially targets septal GABAergic cells (Tóth et al., 1993; Gulyás et al., 2003). On the other hand, type 1 slow-firing cells were over-represented among cells with the slow response (75\%, or 18 of 24 responding cells; Fig. $7 B$, right). All other cell types were underrepresented, including the type 2 slowfiring cells (only one of which had a slow response). In an analysis of the percentage of each cell type that displayed the different response types (Fig. 7C), fast-firing cells were the most likely to have GABAergic responses (37\% responding, 26 of 73 cells), while type 1 slow-firing cells were the most likely to have slow responses ( $25 \%$ responding, 18 of 71 cells). In total, the distribution of cell types displaying the two response types was very different $(p=0.0024)$.

We conclude that the HS projections elicit two types of responses in two independent populations of septal target cells, with the slow response being more prominent after high-frequency (ripple-range) stimulation.

\section{Discussion}

Although septal cell types have been extensively classified in juvenile rats (Markram and Segal, 1990; Gorelova and Reiner, 1996; Morris et al., 1999; Sotty et al., 2003), to our knowledge our work is the first such effort in adult animals (Fig. 2 ). In general agreement with previous studies, we observed fast-firing, clusterfiring, and slow-firing neurons, which approximately correspond with chemical classifications of GABAergic, glutamatergic, and cholinergic cell types (Sotty et al., 2003). Notably, we were unable to clearly identify burst-firing cells, a second type of GABAergic cell previously described (Sotty et al., 2003), perhaps due to a difference between juvenile and adult physiology. Among the slow-firing cells that we identified, the majority (type 1 slow-firing cells) had the canonical cholinergic waveform (Markram and Segal, 1990; Gorelova and Reiner, 1996; Morris et al., 1999; Sotty et al., 2003), colabeled with ChAT on post hoc immunostaining (Fig. 2), and constituted the predominant cell type 
found with targeted patching in ChAT::Cre transgenic rats. We also observed a second population of slow-firing cells (type 2 slow-firing cells) with a narrower and steeper action potential, which were also found among the virus-expressing cells in the transgenic rats. Cells of both slow-firing patterns are therefore likely to be cholinergic, although our data do not preclude the possibility that a subset may coexpress GAD67, or may alternatively express VGluT, as has previously been shown for slowfiring cells in juvenile rats (Sotty et al., 2003). The fact that the two populations of slow-firing cells had differing responses to hippocampal inputs (Fig. 7) suggests that they play functionally different roles in the HS circuit.

In accordance with previous anatomic (Tóth et al., 1993) and physiologic (Manseau et al., 2008) studies, we find that hippocampal input elicits a GABAergic response (Fig. 3) that is biased toward fast-spiking (putative GABAergic) septal cells (Fig. 7). Since many septal cells exhibit rebound spiking following hyperpolarization, this GABAergic input may in fact generate rhythmic firing, as previously shown with electrical stimulation of the fornix/fimbria in an innovative in vitro HS preparation (Manseau et al., 2008). During theta oscillations, therefore, rhythmic GABAergic hippocampal input onto septal cells may synchronize theta-frequency activity, as recently demonstrated with a GABAergic hippocampal projection onto predominantly GABAergic neurons in entorhinal cortex (Melzer et al., 2012). Within the hippocampus, reciprocal connectivity has been demonstrated between HS cells and inhibitory (oriens-lacunosum moleculare) cells, and was shown to promote synchrony of gamma oscillations (Quilichini et al., 2012). It is intriguing to speculate that there may be a similar reciprocal loop between HS cells and fast-firing septal cells that may promote theta synchrony, and indeed HS cells receive direct GABAergic inputs from the medial septum (Takács et al., 2008). During ripples, in contrast, more sustained inhibitory input from hippocampus may contribute to the decreased firing observed in many septal cells (Dragoi et al., 1999).

In an independent subset of septal cells, HS stimulation elicited a slow hyperpolarization and decrease in input resistance (Fig. 4). Based on the calculated reversal potential of the response, and its substantial inhibition by a GIRK channel antagonist (Fig. 5), the evoked current is likely to be largely mediated by potassium ions. However, it is also likely that there are additional evoked currents contributing to the decrease in input resistance while attenuating the extent of hyperpolarization; these may include chloride currents (as expected in the cells that demonstrated IPSCs) and currents through hyperpolarization-activated voltage-gated ion channels (such as hyperpolarization-activated cyclic nucleotide-gated cation channels or low-threshold calcium channels) that may open as a consequence of GIRK channel activation.

The simplest models to explain the slow response would be either (1) GABA release and activation of GABA receptors on postsynaptic cells or (2) SST release and activation of SSTRs on postsynaptic cells. However, these are both inconsistent with the entirety of our experimental data. The response is not sensitive to $\mathrm{GABA}(\mathrm{B})$ receptor blockers, and previous work suggests postsynaptic $\mathrm{GABA}(\mathrm{B})$ receptors are mainly active on GABAergic septal neurons (Henderson and Jones, 2005). Tonic GABA(A) receptor-mediated currents are insensitive to barium, and the reversal potential of the response does not suggest a pure chloride conductance as would be expected with an ionotropic GABA receptor. Additionally, evoked IPSCs and slow responses were seen in independent cell populations (Fig. 7). Regarding possible direct activation of postsynaptic SSTRs, the slow response was neither inhibited by an SST2AR antagonist nor mimicked by an SST2AR agonist, where SST2AR is the SSTR cell type most abundantly expressed on somata in the adult rat medial septum (Thoss et al., 1995; Fehlmann et al., 2000). Furthermore, the evoked slow response was predominantly found in slow-firing cells, whereas SST2ARs are expressed on GABAergic neurons (Bassant et al., 2005). Together, our results suggest that a direct postsynaptic GABA-receptor-mediated or SST2-receptor-mediated current does not underlie the slow response.

Since the simple models described above are inconsistent with our data, we conclude that the mechanism underlying the slow response is more complex, possibly involving circuit elements in addition to the HS fibers and the target septal cells. In support of this, we found that the slow response was profoundly inhibited by the D2 receptor antagonist prochlorperazine (Fig. 5). Prochlorperazine has also been reported to interact with several other receptor types to a lesser extent (Peroutka and Snyder, 1982; Boublik and Funder, 1984; Hamik and Peroutka, 1989; Lummis and Baker, 1997). However, our finding that bath application of quinpirole (a D2 agonist) mimicked the slow response in slowfiring cells (Fig. 5) argues in favor of a D2R-mediated effect.

Although D2 receptors have been found in the medial septum (Weiner et al., 1991), little is known about dopaminergic regulation of septal cholinergic signaling. Intriguingly, systemic in vivo quinpirole administration has been shown to decrease hippocampal acetylcholine release (Day and Fibiger, 1994), which would be consistent with our findings. The precise mechanistic connection between HS stimulation and D2 receptor activation remains unclear. There are two main hypotheses consistent with all of our pharmacological data (i.e., partial inhibition by barium, nonselective SST-receptor antagonists, and D2-receptor antagonists), which could explain the mechanism underlying the slow response.

In the first model, optogenetic stimulation results in postsynaptic induction of dopamine release, with dopamine then binding D2Rs on target septal cells. Previous histological analysis of the HS projection found that a majority of HS synaptic targets are onto dendritic shafts (Tóth et al., 1993), which could support this model. Some literature suggests that GABA may potentiate dopamine release through an unknown mechanism (Starr, 1978), although this would not explain the observed inhibition by SSTR antagonists. SST induction of dopamine release has been demonstrated several times (Chesselet and Reisine, 1983; Hathway et al., 1998; Pallis et al., 2001; Marazioti et al., 2008), although the mechanisms remain unknown. In the second model, released SST acts via hybrid SSTR/D2R heterooligomers, which have been shown to be pharmacologically distinct from the constituent receptor homodimers (Rocheville et al., 2000; Baragli et al., 2007). The response of these hybrid receptors to various agonists or antagonists of either variety has not been characterized in detail, but if this receptor hybridization occurs within the medial septum, then this model could in theory also be consistent with all of our pharmacology results.

While the fast, GABAergic septal response to HS input fits well into the existing literature about the circuit, the slow, modulatory septal response has not previously been described. Membrane potential hyperpolarization and decreased input resistance are both expected to lead to a decrease in excitability and thus decreased spike rate. Decreased excitability of septal cholinergic cells would likely lead to decreased cholinergic tone in the hippocampus, attenuating, although not abolishing, hippocampal theta oscillations (Lee et al., 1994; Teles-Grilo Ruivo and Mellor, 
2013). Our analysis of the response kinetics (Fig. 6) suggests that these changes may occur on a timescale of seconds, although shorter bursts of high-frequency HS activity, as seen physiologically during ripples, may cause briefer, nonsaturating effects. Intriguingly, recent in vivo recordings in awake animals identify a subpopulation of slow-firing, putative cholinergic cells that seem to promote hippocampal theta amplitude on a similarly slow timescale (Zhang et al., 2011). Therefore, although the hippocampus is capable of dynamically switching back and forth between theta and sharp wave/ripples following changes in animal behavior (Kramis et al., 1975), our results raise the possibility that the larger HS circuit is also subject to slow modulation, which may bias, although not dictate, the state of the network. Our results also point to an interaction between the HS and dopaminergic projections to the medial septum, and between cholinergic and dopaminergic modulatory systems in the larger circuit.

Our work highlights the flexibility and complexity of neuronal processing. While the fast, GABAergic response was readily evoked at both high and low frequency, the slower, presumptively G-protein-coupled response was much stronger in response to high-frequency stimulation. In conclusion, we demonstrate that the same projection can mediate two distinct downstream responses, communicated across different timescales and in independent cell populations.

\section{References}

Baragli A, Alturaihi H, Watt HL, Abdallah A, Kumar U (2007) Heterooligomerization of human dopamine receptor 2 and somatostatin receptor 2 Co-immunoprecipitation and fluorescence resonance energy transfer analysis. Cell Signal 19:2304-2316. CrossRef Medline

Bassant MH, Simon A, Poindessous-Jazat F, Csaba Z, Epelbaum J, Dournaud P (2005) Medial septal GABAergic neurons express the somatostatin $\mathrm{sst}_{2 \mathrm{~A}}$ receptor: functional consequences on unit firing and hippocampal theta. J Neurosci 25:2032-2041. CrossRef Medline

Boublik JH, Funder JW (1984) Interaction of dopamine receptor ligands with subtypes of the opiate receptor. Eur J Pharmacol 107:11-16. CrossRef Medline

Chapman CA, Lacaille JC (1999) Cholinergic induction of theta-frequency oscillations in hippocampal inhibitory interneurons and pacing of pyramidal cell firing. J Neurosci 19:8637-8645. Medline

Chesselet MF, Reisine TD (1983) Somatostatin regulates dopamine release in rat striatal slices and cat caudate nuclei. J Neurosci 3:232-236. Medline

Day JC, Fibiger HC (1994) Dopaminergic regulation of septohippocampal cholinergic neurons. J Neurochem 63:2086-2092. Medline

Dragoi G, Carpi D, Recce M, Csicsvari J, Buzsáki G (1999) Interactions between hippocampus and medial septum during sharp waves and theta oscillation in the behaving rat. J Neurosci 19:6191-6199. Medline

Fehlmann D, Langenegger D, Schuepbach E, Siehler S, Feuerbach D, Hoyer D (2000) Distribution and characterisation of somatostatin receptor mRNA and binding sites in the brain and periphery. J Physiol Paris 94: 265-281. CrossRef Medline

Freund TF, Antal M (1988) GABA-containing neurons in the septum control inhibitory interneurons in the hippocampus. Nature 336:170-173. CrossRef Medline

Gerashchenko D, Salin-Pascual R, Shiromani PJ (2001) Effects of hypocretin-saporin injections into the medial septum on sleep and hippocampal theta. Brain Res 913:106-115. CrossRef Medline

Girardeau G, Benchenane K, Wiener SI, Buzsáki G, Zugaro MB (2009) Selective suppression of hippocampal ripples impairs spatial memory. Nat Neurosci 12:1222-1223. CrossRef Medline

Gorelova N, Reiner PB (1996) Role of the afterhyperpolarization in control of discharge properties of septal cholinergic neurons in vitro. J Neurophysiol 75:695-706. Medline

Goutagny R, Jackson J, Williams S (2009) Self-generated theta oscillations in the hippocampus. Nat Neurosci 12:1491-1493. CrossRef Medline

Greene JR, Mason A (1996) Effects of somatostatin and related peptides on the membrane potential and input resistance of rat ventral subicular neurons, in vitro. J Pharmacol Exp Ther 276:426-432. Medline
Gulyás AI, Hájos N, Katona I, Freund TF (2003) Interneurons are the local targets of hippocampal inhibitory cells which project to the medial septum. Eur J Neurosci 17:1861-1872. CrossRef Medline

Hamik A, Peroutka SJ (1989) Differential interactions of traditional and novel antiemetics with dopamine D2 and 5-hydroxytryptamine 3 receptors. Cancer Chemother Pharmacol 24:307-310. CrossRef Medline

Hathway GJ, Emson PC, Humphrey PP, Kendrick KM (1998) Somatostatin potently stimulates in vivo striatal dopamine and gamma-aminobutyric acid release by a glutamate-dependent action. J Neurochem 70:1740 1749. Medline

Henderson Z, Jones GA (2005) GABAB receptors in the medial septum/ diagonal band slice from $16-25$ day rat. Neuroscience 132:789-800. CrossRef Medline

Huh CY, Goutagny R, Williams S (2010) Glutamatergic neurons of the mouse medial septum and diagonal band of Broca synaptically drive hippocampal pyramidal cells: relevance for hippocampal theta rhythm. J Neurosci 30:15951-15961. CrossRef Medline

Jinno S, Kosaka T (2002) Immunocytochemical characterization of hippocamposeptal projecting GABAergic nonprincipal neurons in the mouse brain: a retrograde labeling study. Brain Res 945:219-231. CrossRef Medline

Jinno S, Klausberger T, Marton LF, Dalezios Y, Roberts JD, Fuentealba P, Bushong EA, Henze D, Buzsáki G, Somogyi P (2007) Neuronal diversity in GABAergic long-range projections from the hippocampus. J Neurosci 27:8790-8804. CrossRef Medline

Knapp JA, Morris NP, Henderson Z, Matthews RT (2000) Electrophysiological characteristics of nonbursting, glutamate decarboxylase messenger RNA-positive neurons of the medial septum/diagonal band nuclei of guinea-pig and rat. Neuroscience 98:661-668. CrossRef Medline

Kramis R, Vanderwolf CH, Bland BH (1975) Two types of hippocampal rhythmical slow activity in both the rabbit and the rat: relations to behavior and effects of atropine, diethyl ether, urethane, and pentobarbital. Exp Neurol 49:58-85. CrossRef Medline

Lee MG, Chrobak JJ, Sik A, Wiley RG, Buzsáki G (1994) Hippocampal theta activity following selective lesion of the septal cholinergic system. Neuroscience 62:1033-1047. CrossRef Medline

Lesage F, Guillemare E, Fink M, Duprat F, Heurteaux C, Fosset M, Romey G, Barhanin J, Lazdunski M (1995) Molecular properties of neuronal G-protein-activated inwardly rectifying K+ channels. J Biol Chem 270: 28660-28667. CrossRef Medline

Levey AI, Edmunds SM, Hersch SM, Wiley RG, Heilman CJ (1995) Light and electron microscopic study of $\mathrm{m} 2$ muscarinic acetylcholine receptor in the basal forebrain of the rat. J Comp Neurol 351:339-356. CrossRef Medline

Lummis SC, Baker J (1997) Radioligand binding and photoaffinity labelling studies show a direct interaction of phenothiazines at 5-HT3 receptors. Neuropharmacology 36:665-670. CrossRef Medline

Manseau F, Danik M, Williams S (2005) A functional glutamatergic neurone network in the medial septum and diagonal band area. J Physiol 566:865-884. CrossRef Medline

Manseau F, Goutagny R, Danik M, Williams S (2008) The hippocamposeptal pathway generates rhythmic firing of GABAergic neurons in the medial septum and diagonal bands: an investigation using a complete septohippocampal preparation in vitro. J Neurosci 28:4096-4107. CrossRef Medline

Mansour A, Fox CA, Burke S, Meng F, Thompson RC, Akil H, Watson SJ (1994) $\mathrm{Mu}$, delta, and kappa opioid receptor mRNA expression in the rat CNS: an in situ hybridization study. J Comp Neurol 350:412-438. CrossRef Medline

Marazioti A, Pitychoutis PM, Papadopoulou-Daifoti Z, Spyraki C, Thermos $\mathrm{K}$ (2008) Activation of somatostatin receptors in the globus pallidus increases rat locomotor activity and dopamine release in the striatum. Psychopharmacology (Berl) 201:413-422. CrossRef Medline

Markram H, Segal M (1990) Electrophysiological characteristics of cholinergic and noncholinergic neurons in the rat medial septum-diagonal band complex. Brain Res 513:171-174. CrossRef Medline

Mattis J, Tye KM, Ferenczi EA, Ramakrishnan C, O'Shea DJ, Prakash R, Gunaydin LA, Hyun M, Fenno LE, Gradinaru V, Yizhar O, Deisseroth K (2012) Principles for applying optogenetic tools derived from direct comparative analysis of microbial opsins. Nat Methods 9:159-172. CrossRef Medline

Melzer S, Michael M, Caputi A, Eliava M, Fuchs EC, Whittington MA, 
Monyer H (2012) Long-range-projecting GABAergic neurons modulate inhibition in hippocampus and entorhinal cortex. Science 335:15061510. CrossRef Medline

Mihara S, North RA, Surprenant A (1987) Somatostatin increases an inwardly rectifying potassium conductance in guinea-pig submucous plexus neurones. J Physiol 390:335-355. Medline

Morris NP, Harris SJ, Henderson Z (1999) Parvalbumin-immunoreactive, fast-spiking neurons in the medial septum/diagonal band complex of the rat: intracellular recordings in vitro. Neuroscience 92:589-600. CrossRef Medline

Pallis E, Thermos K, Spyraki C (2001) Chronic desipramine treatment selectively potentiates somatostatin-induced dopamine release in the nucleus accumbens. Eur J Neurosci 14:763-767. CrossRef Medline

Peroutka SJ, Snyder SH (1982) Antiemetics: neurotransmitter receptor binding predicts therapeutic actions. Lancet 1:658-659. Medline

Quilichini PP, Le Van Quyen M, Ivanov A, Turner DA, Carabalona A, Gozlan H, Esclapez M, Bernard C (2012) Hub GABA neurons mediate gammafrequency oscillations at ictal-like event onset in the immature hippocampus. Neuron 74:57-64. CrossRef Medline

Rivkees SA, Price SL, Zhou FC (1995) Immunohistochemical detection of Al adenosine receptors in rat brain with emphasis on localization in the hippocampal formation, cerebral cortex, cerebellum, and basal ganglia. Brain Res 677:193-203. CrossRef Medline

Rocheville M, Lange DC, Kumar U, Patel SC, Patel RC, Patel YC (2000) Receptors for dopamine and somatostatin: formation of heterooligomers with enhanced functional activity. Science 288:154-157. CrossRef Medline

Schweitzer P, Madamba SG, Siggins GR (1998) Somatostatin increases a voltage-insensitive $\mathrm{K}+$ conductance in rat $\mathrm{CAl}$ hippocampal neurons. J Neurophysiol 79:1230-1238. Medline

Sims SM, Lussier BT, Kraicer J (1991) Somatostatin activates an inwardly rectifying $\mathrm{K}+$ conductance in freshly dispersed rat somatotrophs. J Physiol 441:615-637. Medline

Sotty F, Danik M, Manseau F, Laplante F, Quirion R, Williams S (2003) Distinct electrophysiological properties of glutamatergic, cholinergic and GABAergic rat septohippocampal neurons: novel implications for hippocampal rhythmicity. J Physiol 551:927-943. CrossRef Medline

Starr MS (1978) GABA potentiates potassium-stimulated 3H-dopamine release from slices of rat substantia nigra and corpus striatum. Eur J Pharmacol 48:325-328. CrossRef Medline
Takács VT, Freund TF, Gulyás AI (2008) Types and synaptic connections of hippocampal inhibitory neurons reciprocally connected with the medial septum. Eur J Neurosci 28:148-164. CrossRef Medline

Tan W, Janczewski WA, Yang P, Shao XM, Callaway EM, Feldman JL (2008) Silencing preBotzinger complex somatostatin-expressing neurons induces persistent apnea in awake rat. Nat Neurosci 11:538-540. CrossRef Medline

Teles-Grilo Ruivo LM, Mellor JR (2013) Cholinergic modulation of hippocampal network function. Front Synaptic Neurosci 5:2. CrossRef Medline

Thoss VS, Perez J, Duc D, Hoyer D (1995) Embryonic and postnatal mRNA distribution of five somatostatin receptor subtypes in the rat brain. Neuropharmacology 34:1673-1688. CrossRef Medline

Tóth K, Borhegyi Z, Freund TF (1993) Postsynaptic targets of GABAergic hippocampal neurons in the medial septum-diagonal band of broca complex. J Neurosci 13:3712-3724. Medline

Tóth K, Freund TF, Miles R (1997) Disinhibition of rat hippocampal pyramidal cells by GABAergic afferents from the septum. J Physiol 500:463474. Medline

Twery MJ, Gallagher JP (1989) Somatostatin hyperpolarizes neurons and inhibits spontaneous activity in the rat dorsolateral septal nucleus. Brain Res 497:315-324. CrossRef Medline

Van der Zee EA, Luiten PG (1994) Cholinergic and GABAergic neurons in the rat medial septum express muscarinic acetylcholine receptors. Brain Res 652:263-272. CrossRef Medline

Weiner DM, Levey AI, Sunahara RK, Niznik HB, O’Dowd BF, Seeman P, Brann MR (1991) D1 and D2 dopamine receptor mRNA in rat brain. Proc Natl Acad Sci U S A 88:1859-1863. CrossRef Medline

Witten IB, Steinberg EE, Lee SY, Davidson TJ, Zalocusky KA, Brodsky M, Yizhar O, Cho SL, Gong S, Ramakrishnan C, Stuber GD, Tye KM, Janak PH, Deisseroth K (2011) Recombinase-driver rat lines: tools, techniques, and optogenetic application to dopamine-mediated reinforcement. Neuron 72:721-733. CrossRef Medline

Wolak ML, DeJoseph MR, Cator AD, Mokashi AS, Brownfield MS, Urban JH (2003) Comparative distribution of neuropeptide Y Y1 and Y5 receptors in the rat brain by using immunohistochemistry. J Comp Neurol 464: 285-311. CrossRef Medline

Zhang H, Lin SC, Nicolelis MA (2011) A distinctive subpopulation of medial septal slow-firing neurons promote hippocampal activation and theta oscillations. J Neurophysiol 106:2749-2763. CrossRef Medline 